\title{
A IDEALIZAÇÃO DE ROMA E A SUA ACEITAÇÃO PELOS CRISTÃOS (III)
}

\author{
(Continuação)
}

\section{CAPITULO III}

\section{ROMA COMO ENTIDADE DO BEM NA EPOCA DE AUGUSTO}

Vimos, no capítulo anterior, tôda uma corrente de idéias antiromanas, pregando o início de uma éra feliz, assinalada pela queda de Roma, cujo castigo teria sido decidido pela Divindade em virtude dos crimes cometidos contra os povos dominados, particularmente o judeu. Roma surgia, assim, como legítima entidade do Mal. Veremos agora exatamente o contrário: o início de uma nova idade do ouro, graças a Roma, restauradora do equilíbrio do mundo, encarnaçäo đo Bem, pelo grande benefício de estabelecer a paz entre os povos.

Já nos referimos antes ao ambiente sombrio em que se passaram os últimos tempos da República, ambiente êste que condicionara o tão melancólico prefácio de Tito-Livio e que acabara por determinar uma reação da elite romana, por meio do desenvolvimento da idéia da eternidade de Roma. Ora, a inquietude dominante na época gerou, neturalmente, entre os contemporâneos, uma enorme aspiração à paz, e esta aspiração, fundindo-se à crença então existente nas idades do Mundo, fêzz com que surgisse na literatura um tema completamente novo entre os romanos: o do retôrno da Idade do Ouro, caracterizada acima de tudo pela paz, no seu sentido mass amplo. $O$ que há de interessante para nós, é que êste tema, tratadc a princípio de maneira muito geral, acabou por contribuir com um poderoso elemento para a elaboração do que podemos chamar a "Lenda de Roma"; de fato, a cidade que pacificara o mundo fizera algo realmente digno da gratidão dos homens e podia ser considerada, não apenas uma simples cidade, mas muito mais: como uma entidade benéfica, sob cujo signo ressurgiria a Idade do Ouro.

Assim, contrabalançar-se-ia a corrente anti-romana de origem oriental juđaica, e às predições sôbre a queda de Roma seria opos- 
ta a crenca tha "Roma Aeterna", predestinada a garantir a paz no mumito por todos os tempos, encabeçando um império cujas pretensōes ao domínio mundial justificar-se-iam pela sua extraordinária capacidade civilizadora (1).

Tratemos de demonstrar, entā́, de que maneira se realizon êste processo, e principiesnos pelas condiçóes de inquietude que, agindo sâbre uma tendência otimista, tiversm resultado completamente opasto a tudo quanto fôra apregcado pelos pessimistas e inimigos di potíncia rcmana.

Deside as crises revolucionárias do século II a C e particulermente, desde a época de Sila, os romanos passavam por transtoranos sucessivos determinades pelos conflitos políticos e saciais e pelas crises de caráter econômica. Tudo isto, associado a uma sírie de crenças a que já nos réerimos, fizera com que, desde 184, os ramanos esperassem o fim catas rófico da cidade, ccasiāo em que Catāo resotvera a dúvida por meio do famoso episódio das tendas (2) i a mesma cousa sucedera em 8483, quando do incêndio to Capitotra, e em seguida, com intervalos de 10 anos, verificaramse fates que podiam ser interpretados como prenunciadores da täo temida catástrofe final: em 73, o incesto das Vestais; em 63, a conjuraçäo de Catilina; em 53, a derrota e morte de Crasso em Carras; e em 43, a morte de Cícera, que, de acôráo com a sua própria frase, havia satvo a República quando esta fôra alvo das ameaças de Catalina (3). E que "as revoluçōes, as proscrições, as mudanças sucessivas nas relaçōes de posse, a desorganização sacial decorrente de tudo isto, assim como o desencadeamento das paixões favorecido pelas circunstâncias, pesavam dolorosamente sôbre os romanos Tinha-se a sensação de que uma inexpiável maldição agia continuamente através das geraçöes, levando-lhes a guerra civil, o assassínio dos concidadãos e violéncias cạda vez mais intensificadas e renovadas (4). "Tôda esta intranqüilidade repercutia profundamente sôbre o espiriio dos romanos, que nunca sabiam ao certo o que thes daria o dia seguinte, vivendo assim num grande desequilíbrio psicológico (5).

O conhecimento desta atmosfera de angústia nos ajuda a compreender melhor certas passagens de alguns dos mais importantes autores dos últimos temprs da República, assim como Catulo, que é détuimiäo que os deuses abandonaram o munda, entre-

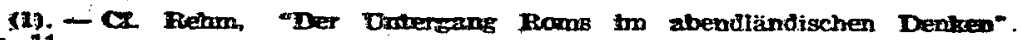
Dafe. 14

(2). - Tho-ivio, XXXDe, 48

(3). - Tielmski. "La sibyjle", whe.

(4). - Wendland, H.R.K." págs. 142-143; C1. Hahn, "Das Kaisertum". Ptge. $5-\mathbf{a}$

(5). - Purtovtzeff. "Historia social y econúmica del Imperio Romano". I, $_{0}$ pug. 67: Ce. Cochrane, "Cristianismo s cultura clasica", pags. 38 e 88. 
gando-o à destruição (6), Lucrécio, na sua melancólica passagem do "De Natura rerum" II, 1150-1175, Salústio, na introdução . à "De bello Iugurthinc" e Horácio, que procura explicar os males de seu tempo como um castigo por algum grande crime que Roma tivesse outrora comeido (7). Tal ambiente- deu margem, como já vimos antes, à divulgação de uma série de augúrios a respeito do próximo fim da cidade, convindo lembrár que a tradição da divisão da história do mundo em idades, utilizada pelos adivinhos etruscos, fêz com que vários acontecimentos fôssem tidos como sinais de que uma éra estava prestes a se encerrar, para ceder lugar a outro perícdo.

$\mathrm{S}$ a considerarmos apenas êstes dois elementos, cu seja, a tradição das idades e as crenças etruscas, seremos levadós à conclusão de quie não havia margem para que se acreditasse no reinício da Idzde do Ouro, uma vez que nem Hesícdo nem Arato tratam da possibilidade de sua volta, e que os etruscos também não aventavam hipótese alguma de rejuvenescimento do Estado, fôsse êle qual fôsse. E temos razão para supor que tal idéia tivesse agido sôbre os romanos, visto que Varrão e Cícero a mencionam (8), e também que os textos etruscos, conhecidos por "livros de Vegonia", foram traduzidos para o latim e conservados no templo de Apslo juntamente com os livros sibilinos (9). Ao contráric, o que se observa nos meados do século I a $C$. é justamente a manifestação da crença no iminente reinício da Idade do Ouro, crença esta que se exterioriza com particular intensidade na famcsa IVa. écloga. Ora, a principal característica desta sonhada Idade do Ouro era o fim das guerras e o estabelecimento da paz no mundo mediterrâneo, sob a égide de Roma, com a estabilização de govêrno e a ex!inção das guerras civis; e se, como parece, entre as tradiçōes etruscas e os autores gregos não havia base para supor-se um reinício da Idade do Ouro para Roma, o único caminho é procurar quais as outras influências que agiram sôbre o espírito dz pceta, se é que houve influências.

Ver-se-á, então, que o contato cada vez mais intenso com o Oriente helení:ico favorecera, desde a época de Sila, o desenvolvimento de uma verdadeira "efervescência messiânica (10)", e que foi nesta mesma época que, no Oriente, Mitridates pôde apresentar-se como um verdadeiro Messias, destinado a marcar o início de uma éra de felicidade mas, é verdade, obtida à custa da

(6). - 64, conciusão: "Quando, confundindo o sagrado e o profano, um delirio culpável lerantcu contra nós a justa cólera dos deuses; desde então eles nāo mais estiveram presentes às nossas assembléias, e nāo maís toleraram que dểes nos aproxinússemos na luz clara".

(7). - Carr. 1, 2, 35; 35, 3.3; II. 2; ill, 6, principio e fim; 24, 25; Ep. VII cf. Wendlañ, op. loc. cit.; Huchan, “Augustus”, págs.-89-90.

(8). - Lucati, "Le problene étrusque". pag. 159; Nogara, "Les etrusques, ct leur civilisation", pag. 107; Ilerbig, art. "Etruscan religion", in Enc. of Religion and Ethics.

(9). - Nogara, op. cit., pág. 233.

(10). - Jecnniaire, "Le nucssianisine de Virgile", pág. 144. 
derrota e da ruína de Roma (11). Parece-nos razoável que tais predições chegassem até Roma, contribuindo para que os seus cidadãos - que acabaram por derrotar a Mitridates, desmentindo assim suas previsōes - adotassem para si e em seu favor as mesmas idéias; acrescente-se ainda, a isto, a divulgação da crença helenístico-oriental no chefe do Estado como "uma fôrça salvadora, redentora, geradora de ordem e de paz (12)." E é de sobêjo conhecida a influência das idéias importadas do Mediterrâneo Oriental sôbre o próprio Sila, que pretendeu ser o restaurador da paz no mundo mediterrâneo, apresentando-se como favorito dos deuses, particularmente de Afrodite (13).

A paitir daí, nada mais natural do que o incremento das esperanças do tipo messiânico, intensificadas por dois grandes fatôres: em primeiro lugar, porque a não cessação das lutas aumentava \& aspiração à paz; em segundo, porque não cessaram de agir sôbre os romanos as pređiçooes de origem oriental. Interessante é que, dentro de tôdas as hipóteses e divergências que existem em tôrno da explicação das prediçõ̂es relativas ao retôrno da Idade do Ouro em Roma, pode ser distinguido um traço de concordância, que é a inspiração helenístico-oriental. Para exemplificar nossa afirmativa tomemos alguns dos autores que se dedicaram ao assunto.

Bellessort, "um dos mais finos e penetrantes comentaristas de Virgílio (14)", é de opinião que "a predição da Sibila, à qual Virgílio faz alusão, é provàvelmente uma destas composições judaicas e messiânicas que ccrriam pelo Oriente e que eram transportadas para Roma, a menos - o que é muito verossímil - que êle tenna podido consultar os "Libri fatales" ou cantos sibilinos. Elaborados por judeus de Alexandria, foram êles vendidos aos delegados do Senado Romano, quando, em 83 a. C. o incêndio do templo de Júpiter devorou os verdadeircs livros da Sibila, reunidos sob Tarquínio". "... justamente Virgílio, que tem o senso religioso e a curiosidade dos mistérios, acaba de ler as predições orientais; possui algumas noções do Orfismo; conhece os velhos oráculos etruscos (15)." Jeanmaire, que com tanto afinco defende o ponto de vista da estreita relação entre a IV écloga e a política religiosa de Antônio e de Cleópatra no Oriente, pela própria natureza de sua tese, é levado a admitir várias influências helenísticas na pequena cbra de Virgílio; vêmo-lo, assim, afirmando que se encontram nos oráculos sibilinos expressões e imagens que ofe-

(I1). - Ateneu, $\% 213$ b: Salústio, Hist., IV, 69: Justino, Epit., XXXVIII, 6; Apiano, XII. 10. Ap. Sanford, "Contrasting rjews", pág. 439.

(12). - Bousset. "Die Religion". pás. 225.

(13). - Cr. Carcopino. "La Fépublique Romaine de 133 a 44 a.C.", pág.

491; idem, "Sylia ou la monarchie manquee", pág. 94 e ss..

(14). - Jeanmaire, "Le Messianisme de Virgile", pág. 13.

(15). - Eellessort, "Virgile, son oeuvre et son temps", págs. 62-63 e 68. 
recem incontestável parentesco com a IV écloga (16), e que a importância desta poesia (dedicada a um agente de Antônio), reside principalmente no fato de poder ser ela interpretada camo fazendo eco a um oráculo que nos mostra o tema apocalíptico a serviço dos planos do triúnviro, numa primeira fase de sua política, quando êle ainda se apoia sôbre Alexandria e obedece aos impulsos de sua rainha; o velho oráculo sibilino acima comentado (17), se nós o datarmos, com W. Tarn, dos tempos que precederam Actium, mostra-nos um recrudescimento da atividade da mesma propaganda, quando a rainha e 0 antigo lugar-tenente de César novamente uniram seus destinos (18). Noutra passagem, tratando da pintura feita por Virgílio da paz, paz completa, de que participariam não só os homens, mas também os animais, o mesmo autor; ainda que ligeiramente, năo afasta a possibilidade de que tal quadro possa apresentar sérias analogias com Isaias e outras pinturas de caráter messiânico (19); è foi ainda êste tema da paz que chegou a lançar dúvidas no espírito do erudito Lagrange que, repelindo a hipótese da existência de messianismo na IV écloga, e tratando da questão das relações enttre Virgílio e os sibilinos judeus (20), expresșa-se de maneira bem interessante: "Virgílio inspirouse nestes traços? - Se optarmos pela afirmativa, se Horácio está no mesmo caso, deve-se concluir que a Sibila judia encontra crédito entre as mais nobres inteligências do paganismo, que a fraude tivera sucesso? - Este apaixonante problema é sempre discutido. Nós próprios concluimos contra o messianismo de Virgílio (21). E parece-nos sempre que a IV écloga não deve o seu pressentimento de uma idade do ouro às esperanças judias. Restava-nos um escrúpulo, esta alusão de Virgílio à mansuetude dos animais ferozes, traço juđeu (22) que não tínhamos encontrado entre os pagãos a não ser em Virgílio e em Horácio, que podiam ter-se comunicado entre si. Mas, enfim, encontrâmo-lo em Teócrito (23), que esteve no Egito após 275 a. C., antes, portanto, da composição do III livro sibilino. Virgílio, que dêle tomou tantos traços, pode ter-se inspirado também neste (24)".

Tal passagem pareceria suficiente para desfazer qualquer afirmativa de parentesco entre os sibilinos judeus e a IV écloga,

(16). - "La Sibylle", pág. 55.

(17). - Idem, idem, tratando dos versos 350-380 do III livro dos oráculos.

rf. Tarn e Charlesworth, in "Cambridge Ancient History"; $\mathrm{X}$, págs. $68 \mathrm{e}$ os..

(18). - Idem, pág. 65-66.

(19). - "I_e Messianisme de Virgile", pág. 73.

(20). - Neste caso, III, 785-795. $552-72$.

(21). - "Le prétendu Messianisme de Virgile", in "Revue Biblique", 1922,

(22). - Cf. "Le prétendu Messianisme de Virgile", pág. 563: "De l'influen-e orientaie on a er effet relevé deux indices, repondant précisement aux deux ićées qui, réunies, font l'originalité de l'églogue: le retour de l'âge d'or et la coïncidence de la prospérité avec la naissance de l'enfant".

(23). - "Hercuies criança", 83 e ss..

(24). - "Le Judaïsme ivant Jésus-Christ", págs. 510-511. 
por parte do referido autor. Entretanto, se aprofundarmos um pouco mais a nossa pesquisa, levando a questão para o campo das relaçōes indiretas com o Oriente, veremos que já a posição de Lagrange não é tão rígida, urna vez que admite as relaçōes entre a Sibila pagã e o Oriente, afirmando também a analogia de traços entre os oráculos pagãos, de que Virgílio ter-se-ia utilizads, e as ameaças dos profetas de Israel (25). Aliás, mesmo negando a ligação entre o quadro da paz na IV écloga e o dos cráculos sibilinos judeus, Lagrange nãs deixa de mencionar a semelhança de tal pintura com a que se encontra em Isaias, XI, 6-9; sairíamo:, assim, dos oráculos, mas não deixaríamos de ficar dentrc da esfera judaica (26).

S. Reinach é bastante explícito, e defende a relação en're a IV écloga e os oráculos judeus: "Nada prova - e é mesmo improvável - que Virgílio tenha tido sob os olhos o texto atual dos Sibyllina. Esta literatura-apócrifa sofreu numerossíssimas transformsçōes anies de se fixar nos manuscritos que nô-la transmitiram. Mas desde que êle próprio cita, no início de seu poema, um canto sibilino, e que êste poema oferece semelhanças evidentes ccm o que possuimos, é natural concluir que uma composição dêste gênero, animada do mesmo espírito judaico e messiânico é uma das fontes principais da IV écloga e explica suas afinidades com - cap. XI de Isaias (27)". O mesmo autor vai ainda além, porquanto admite como a segunda das fonies do pequeno poema o orfismo helênico, e lembra a preocupação de judtus e dos primeiros cristãos de ligar Orfeu, tanto ao Judaísmo - fazendo dêle um discípulo de Moisés - como ao Cristianismo - do qual seria uma espécie de precursor (28). Ora, é evidente que não queremos dizer que o crfismo fôsse judeu, mas vemos a IV écloga e o Judaísmo relacionados também pelo orfismo, através da identidade de inspiração.

Outros autores fazem também notar a semelhança de aspiríções entre o mundo judeu-helenístico e 0 romano, simbolizado principalmente por Virgílio. Citemos, por exemplo, Bousset (29), Guntermann (30) e, notadamente, Prümm, que adota uma atitude que julgamos bastante objetiva e lógica a respeito do problema. De fato, repelindo o messianismo, distingue êle a profecia de um Salvador da de uma Salvação, ou melhcr, para empregarmos

(25). - Idem, 503. Cf. Prümr, "Christentum als Neuheitserlebnis", pág. 80 e "Der cinrigtliche Glaube". 1, pág. 2ui.

(20). - Op. cit., pág. 511, n. 4.

(27). - "Cultes, Mythes et Religions", II, púg. 72 ; cf. pág. 83.

(28). - Idem, pás. 83 . C1. Martigny, "Dictionnaire des antiquites chrétiennes", art. "Urpléé", jágs. 5i4t-5il.

(29). - "Die Religion", pag. 206: “... der römische Dichter Vergil ist in der eschatologiscken Schilderung der Zukunft, niöglicherweise auch vom Zuhunftsglauben des Judentums, sicher durci orientalische Ideen angeregt". Cf. yág.

(30). - "Die Eschatologie des Hil. Paulus", pág. 1. 
as suas próprias palavras, distingue Heilandsprophetie de Heilsweissagung; mas nem por isso nega a possibilidade de influências judias sôbre Virgílio, aindạ que restritas ao ponto de vista estético (31).

Deixamos propositadamente para o fim desta pequena lista de comentários à IV écloga J. Carcopino, porquanto embora negando qualquer parentesco direto entre Virgilio e cs sibilinós judẹs, acaba êle por afirmar a existência de relações entre a $\mathbf{I V}$ écloga e os judeu-helenísticos. Tais afirmativas são encontradas no excelente volume "Virgile et le mystère de la IVème éclogue", em que 0 autor defende a tese da inspiração neo-pitagórica do pequeno poema, e onde se nota uma acentuada preocupação de raagir à tendência da grande maioria dos comentaristas em atribuir inspiração oriental à IV bucólica, como nos diz expressamente o autor (32). Depois de referir-se a Latâncio, que foi o primeiro a denunciar os empréstimos que Virgílio teria tomado dos sibilinos judeus (33), Carcopino manifesta-se contrário a êste ponto de vista (34), passando a expor os motivos de sua divergência e concluindo, de maneira semelhante à de Lagrange, que apenas o tema da paz poderia dar base a esia relação. Em seguida, defendendo sempre a tese neo-pitagórica, o autor dá ao neo-pitagorismo um papel muito interessante de intermediário entre Virgílio e uma série de influências extranhas à Antiguidade Clássica, iais sejam: egípcias, apciadas por Norden e Boll, através de INigidius Figulus; as do livro de Isaias, graças ao tratado sôbre os judeus, publicado por Alexandre Polihistcr; as judeu-alexandrinas, for meio de Varrão, cujas “Antiguidades" invocavam os oráculos si-

(31). - Der christiiche Glaube", I,pás, 204: “Wir haben In der vierten Thloge eige Heilsweissagung, aber zeine Heilandsprophetie vor uns". Idem, rág. 207. "Es wäre auch wohl anzunelumen, dass Virgil den ästhetischen Reiz inancher Züge der eschatologischen Seite cies israelitischen Messiasreiches bearnder lebhaft verspürt hätte. zumal die. Paradiesesbilder. die die Farben fur lie renanuten Züge der Gestalt urid des Reiches vom Messias hergeben. lebhaft $r_{x}$ die Schilderungen deg goiderien Zeitaiters bei Hesiod erinnern mussten. Aliejn die genannten $u$ enjgen Motiue isonnte Virgil, das darf angesichts unseres jetzigen, wennglcier, noch, nangelhafien Einblickes in das Entstehungsalte: der in den erhaltencn Sibrilinischen Buchern veréinten Stoffe wohl gesagt werden, edenfalls auch in apocrypher judischer Literatur vom Stil der Sibyllinen vorfinden. Auf dieses literaisinie (ienos vieist der Dichter mit der Wendung "Cumaeum Carmen $(v, 1)$ jh ajos a usdrucklich als auf seine Quellen hin".

(32). - "Faute d'avoir "ind leurs investigations du cote des poetes grecs piue ou moins imbus it la:-for pythacoricienue. $d$ Aratos, $p$. ex. et surtout d'Enıpidocle, dont la voix se répercute, comme nous allons tout à l'heure aous en rendre compte, dans les sonorités de la bucolique. les modernes n'en-t-ont retrouvé qu'en dehors de l'antiquité classique les motifs caracteristiques et les expressions décisives; et lon ne suuraft trop louer l'effort des commentateurs les plus recents pour dépister, en deliors des frontières du monde greco-romain. la provenance des idées et des images qui, selon eux, affleurent pour la prémière tis à sd surfact dans le poème "oriental" de Virgile". (pAg. 62).

Sublinheiros a importáncia da obra de Carcopino, o que, allas, e reconhe$\because$ do por Jeanmaire: "Son livre est une maniere de compendium de l'éxégése ite la Ifeme. Wucoligue et, comme tel, sera bien venu de tous ceux qui ont cxpérimenté les difficuités où l'on se trouve jeté par l'extréme disperston de la littérature qui s'y rapporte". "Le Messianisme de virgile", pag. 209).

(3i). - Inst. Div., Vir, 24, 12, ap. Cancopino, op. cit., pag. 65.

(34). - Páge 70-71. 
bilinos (35) e cujo livro "De gente populi romani" expunha a doutrina do cicio secular que a êles se prende (36) e, novamente, Ale-

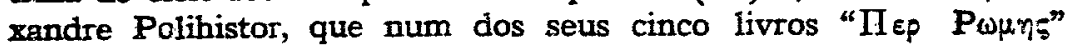
identificou a Sibila de Cumes com uma judia, chamada. Moso (37)"; e as etruscas, que Virgílio não precisava consultar no seu teor original, bastando recorrer a Varrão, "ou ao próprio Nigidius, que incorporaram ao livro VI de seu tratado "De Diis" a substância da sua teologia (38)."

Vê-se, assim, que Carcopino confirma a existência de influências judias, que deveriam ser particularmente importantes para a descrição da paz, exercidas por meio do livro de Isaias ou então, através dos Oráculos Sibilinos, III, 778-779. Chegamos, portanto, à conclusão de que os autores por nós consultados - e que foram os que conseguimos ter à mão - concordam, uns mais, outros menos, com a existência de relações entre os ideais da IV écloga e os expressos pelos judèus. Mas notemos também que se tais relaçōes fôssem indubitàvelmente negadas, isto em nada alteraria o desenvolvimento do nosso plano, uma vez que ficaria evidenciado um fato: a aspiração à paz era um sentimento comum ao mundó greco-romano - simbolizado por Virgílio - e ao judaico, representado pelos oráculos sibilinos dos judeus de Alexandria.

Não podemos deixar de chamar a atenção também para outra possível fonte de inspiração da IV écloga, sempre considerada como símbolo das esperanças de restauração da Idade do Ouro: trata-se da filosofia estóica, segundo a qual haveria periòdicamente a renovação do mundo pelo fogo. Os fragmentos dos estóicos antigos são já suficientes para mostrar suas idéias a êste respeito, particularmente certas passagens de Zeno e que chegaram até nós (39), tratando da doutrina da palingenesia, doutrina esta desenvolvida depois por Crisipo e seus sucessores (40).

Que as idéias estóicas tinham grande voga na época, atestamno os vários fragmentes de autores do Pórtico conhecidos hoje em dia através de literatos de renome no período, assim como Varrão e Cícero (41), e achamos muito difícil que Virgílio, $\mathrm{s} s m$ se ter destacado pela sua capacidade filosófica, tivesse podido escapar às influências de uma corrente de pensamento da envergadura do estoicismo (42). E isto que nos leva a julgar muito rígido o pon-

(35). - Tarrão, ap. Den. Hal., IF, 62 e Tac., An., VI, 12 (cf. Pzach, PaulyVissova, II A.C. 2112)

(36). - Varrão, ap. Santo Agostinho, Civ. Dei, XXII, 28.

(37). - F.Fi.G., III, píg. 200, fr. 25.

(38). - Carcopina op. cit. pú

(39). - Festa, "I frammenti degli stoici antichi", pág. 94. fr. 26. loc. cit.

(40). - Amim, "Stoicorum veterum fragmenta", 'II, 620-631, ap. Festa, op.

(41). - intre os que expuseram a doutrina estúica. sem que eles próprios
enssem tstólcos. Cicero ocupa o prinieiro lugar. Cf. Rodier. "Etudes de philogophie grecque", píf. 24].

(42). - Cf. Rostagni. "La letteratura di Roma republicana ed Augustea". pág. 31.̄. Wendland, "H.P. K", püg. 81 , que. após tratar do desenvolvimentó do filosofia enire os intelectuais rumanos, assim se expressa: "Ein gewisses Gemeingut philosophischer Gedanken bestimmt das Durchschnittsniveau der Bilaung". 
to de vista de Carcopino, afastando qualquer espécie de ligação entre Virgílio e o estoicismo. Embora dando margem a que modernamente se dissesse que êle nada tinha, por temperamento, de um discípulo do Pórtico (43)", o poeta deveria ter sido influenciado pela teoria da renovação periódica do mundo, de tal maneira que, mesmo sem adotar as concepções estóicas com o rigor revelado - por exemplo - no referido fragmento de Zeno, teria retido delas a idéia geral de uma correspondência entre o passado - o presente (44), tanto mais quanto os estóicos também acreditavam numa Idade do Ouro, que teria existido em tempos antiquíssimos. E, pelo menos, a opinião de Pearson (45), que faz notar que, para Zeno, os primeiros homens deviam ser melhores que seus descendentes (46), e que, provàvelmente, para Posidônio (através do Sexto Empírico, "Adv. Math." IX, 28), encontrar-seia na Idade do Ouro o protótipo do born rei

Nessas condições, nada vemos que repugne qualquer espécie de parentesco entre as aspirações simbolizadas no IV écloga e certas idéias da Estoa (47).

Quanto ao mais, quer-nos parecer que a divergência fundamental entre os comentaristas da IV bucólica diz respeito à questão đa maneira pela qual se instauraria a Idade do Ouro, dividindo-se os autores em dois grandes grupos: 0 dos que admitem 0 Messianismo, como Jeanmaire, e o dos que optam pelo Milenartsmo, como Lagrange e Carcopino. Ora, para o nosso caso, pouco

(43). - Bardon, "Les empereurs et les lettres latines d'Auguste à Hadrien", pag. 64. Alias, o meamo autor refere-se a.ecos estóicos em alguns versos dá -Eneida", (p. ex., IV, 412), apoiando-se em Constans, "L'Enéide de Virgile", pág. 148.

(44). - Cf. Jeanmaire, "Le messianisme de Virgile", pág. 96.

(45). - "The fragments of Zeno and Cleanthes", pag. 80, ap. Festa, op. cit., I. pág. ju, notà ao fr. 10. Cf. Jeanmaire, "Le Messianisme de Virgile", păg. $\theta$ $n$ Walser, que assim se expressa: "Die Diskussion tiber die Entartung der Kultur vurde von den Philosophenschulen; for allem der mittleren stoa, gefuhrt. Nach Poseidonios ist der Ưrzustand aller Völker, nicht nur der Römer, ein Zustand idealer Sittlichkeit. Durch Verfall der aiten Sitte und Religion entwikkeit sich die Menschheit $2 \mathrm{um}$ Schlechten". ("Rom, das Reich und die fremden Völker -in der Geschichtsschreibung der Irthen Kaiserzeit", págs. 80-81).

(46). - Nĩo podemos deixar de lembrar aqui uma aignificativa passagem de Horácjo: "O que não é degradado pelo tempo destruidor? A geração de nossos pais, que valiam menos que nossos avós, féz nascer em nós filhos mais inalvados, que väo dar origem a uma pusteridade pior einda". (Odes, III, 6, 45-48).

(47). - Chamemos, equi, a atença para o seguinte fato: 6 sabido o parentesco entre Heraclito e os estóicos, particularmente nas teorias fisicas, tanto assim que Cleantes teria escrito uma "Exposição das toutrinas de Feraclito". loje percida. Oia, remotamente, vamos encontrar um ponto de ligaçäo entre a Sibila pagã e os estóicos, unia vez que a Heraclito seria devida a primeira mençāo da Sibila ("Fabr. bibli. gr.", I, pág. 229, ap. Lücken, "Die sibyllinizchen Weissagungen", pág. U: Prínim, "Seltsaine Heilandspropheten, pág. 468). Tocar-se-iarn, portanto, as idéias estóicas e os sibilinos numa inspiraçăo comum. Para Bousset, aliás, todos êstes elementos, estariam ligados pela fonte comum caldáico-iraniana: "Diese politischen Wirrén, blutigen Bürgerkriege und wirtschaftlichen Notlagen lasteten schwer auf den Menschen des untergehenden Hellenismus und erzeugten tiberall eine Stimmung des Weltuntergengs, der Goetterdänmerung, die zar Weckung des religiösen Sinnes erheblich beitrug. Es war tein. Zufall, dass die iranisch-chaldiatschen Anschauungen vom WeltunterEnug durch Berossos, aurch die Sroa, durch judische und gräko-ägJptische Apolalyptiker, durch hermetische und sibyllinische Schriften verbreitet wurden und bei Ungebildeten und Philosophen, bel Sklaven und Handwerkern gläubigen Anhang fanden ("Die Religion", pág. 203). 
importam as divergências a este respeito, porquanto mantémi-se sempre uma verdade sôbre a qual não há discusião: a Idade do Ourc, que os pagães haviam colocado no passado remoto, apresentava-se, na época em que. Virgílio compôs o seu pequeno poema, como prestes a insiaurar-se novamente no conturbado mundo mediterrâneo, e as características da IV écloga levam-nos à cenciusão de que o poeta tinha "esperanças precisas, ligadas a acontecimentos iminentes (48)."

E é principalmente êste fato que tem determinado a aproximação entre a IV écloga e os judeus, dando mesmo lugar à adoção de posiçōes extremadas, que tendem a reduzir até a importância da relação entre Virgílio e Hesíodo, o que não julgamos um caminho muito viável. As analcgias entre "Os trabalhos e os dias" e o poeta latino seriam, então, superficiais, uma vez que "o espírito que anima cs dois poetas é completamente diferente. Hesiodo, como quase todos os antigos, é pessimista; coloca a Idade do Ouro nas origens da humanidade, fazendo dela um objeto de saudades, e nào de esperanças. Virgílio, ao contrário, saudando a Idade do Ouro que retorna, liga-se à grande tradição otimista da apocalíptica judia, que tem como uma de suas características essenciais esta invencível tenacidade na esperança. A comparação dos versos de Virgílio com a predição apocalíptica do cap. XI de Isaias de um lado, e do outro, com os conhecidos versos de Hesíodo, prova que, se o poeta romano se aproxima de Hesíodo pelos detalhes, êle é bem mais vizinho, pelo espírito, do profeta judeu (49)".

O que nos parece é que não pode ser negada a importância de Hesíodo na elaboração da bucólica em questão (50), mas que influências diversas, e não exclusivamente a jưdia (51), podem ier agido em conjunto sôbre o espírito do poeta, que ansiava pela pacificação de um mundo desde tanto tempo perturbado por convuisóes, fazendo-o retomar o quadro tecido por Hesíodo e prognosticar o retôrno da Idade do Ouro (52).

(4\$). - Jeanmaire, "Le messianiame de Firtrile", pág. 5.

(49). - Sabatier. "Note sur un vers de Virgile". in "ftudes de critique et cl'bistoire" pubicadó pela seçāo de ciencias religiosas da Escola de Altos Estudos, 1s96, ap. Reinach, "Cultes, Mythes et Keligions", II, pág. 69. O próprio Fieinacil, aliás, esclarece ainda o texto de Sabatier: "Bien entendu, $M$. Sabatier n'a pas supposé un instant que Virgile ait pu connaftre une traduction d'Isaïe; mais il lui a été daútart pius aiś́ de determiner ia source intermediaire que Tirgile a pris eoin de la désigner jui-méme. C"est le "Cumaeum carmen". M. sabatier - et, ici. son raisonnement parait lui appartenir en propre, - a donné de bons áreuments pour faire admettre que "Cunaeun Carmen" signifie gimptement "Chant sibullin" (et non pas chant de la sibylle de Cumes) et que le Carmen vige par virkile est une de ces compositions en vers grecs, oeuvres de Juifs

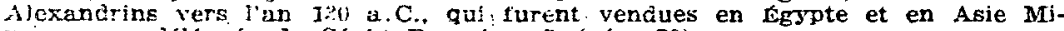
neure aux délêtues du Sérat Romain..." (ṕag. 70).

(3!). - Cr. Carcouno. op. cit., p\&g. $59 \mathrm{e}$ ss., onde se le que, "em mais de uma passagem. Virgiljo pos no futuro os verbos que Heslodo pusera no pasnudo"

(iii). - Cf. Boissier. "La relifion romaine". págs. 260-261.

(32). - Alias, a aspiração de que falamos não devia ser particular a VirElito. estajdo. ao contrario, bastante divulgada na época; tudo isto, entretanto. nāo imode que tenha havido, como dissemos, alguma influência dos oŕculas Eibilinos sobre o poeta. Cf. Christ. "Geschichte der griechischen Literatur". I1, pisg. :ilo, n. 5: Hild, art. "Saeculares Ludj", in "Dictionnaire des Antiquités brecques et Rowaines" de Dareniberg \& Saglio. 
Circunstância realmente interessarice e a que nos permice distinguir, entre os autores que trataram do reinício do periods áurec, duas atitudes diversas - ou melhor - opostas, em relação ao papel a ser desempenhado pela cidade de Roma na nova éra; a primeira, que podemos chamar de otimista, dá margem a que Roma chame a si uma posição de relêvo na instauração da Idade do Ouro, e a segunda, pessimista, prevê o seu desaparecimento como condição prévia para que se restabeleça a éra de felicidade completa sôbre a terra. Vịgílio surge como representante máximo da primeira corrente, e Horácio, com o seu epodo XVI, da segunda (53). Na realidade, a leitura da IV écícga não nos mostra menção expressa alguma de que a Roma devesse caber o papel de in:taurar a Idade do Ourc, mas acredi iamos que alguns motivos pcdem $s a r$ invocados em apôio de uma conclusão positiva. Em primeiro lugar, há a simples verificação de que o poeta não menciona outra região ou cidade como predestinada para es belcs desígnios previstos na bucólica; ora, quer-nos parecer que, se não liá menção alguma, é porque era evidente que Roma estaria integrada no novo período, tanto mais quanto não se compreenderia o jubilo do poeta, êle próprio romano, dirigindo-se a um cônsul romano, se suas predições não favorecessem Roma. Em segundo lugar, fazendo-se o confronto com o XVI epodo, teremos a considerar duas hipóteses: a) -a IV écloga fci anterior ao epodo, e neste caso não se compreenderia o tom de Horácio, completamente descrente da capacidade de restauração de Roma, repelindo o ponto de vista de Virgílio, se não estivesse implícito que a IV écloga se referia à cidade; isto - é claro - porque é ponto pacífico a inter-dependência das duas poesias; b) - a IV écloga foi posterior ao epcdo, e aí, com muito maior razão, Roma é que deveria estax no centro das cogitações do poeta, que afirmaria sua fé na cidade, respondendo ao desânimo de Horácio (54). Por fim, verificamos que nas próprias bucólicas há outra afirmação da crença na cidade, não sendo preciso que se recorra à "Eneida" para que se encontre uma passagem de tão evidente patrio'ismo, como a sıguinte:

(53). - Como é sabido, há grande discugsão em tơno da prioridade da IV fcloga ou do XVI epodo. Poremos de lado a questão, que é de menor importancia para nós, apuiando-nos sôbre o ponto de vista de Carcopino: "E preciso que eu insista sobre o pouco prazer que sinto por estas subtilezas sem resultado. Da comparação intrínseca entre o XVI epodo e a IV écloga, nada poderá iezutar sinão a afirnaçáo de suas relações e a garantia, flagrante mas anónime, de que um dos dois poetas, a escrever o seu trabalho, tinha sob os olhos a obra do outro. Ir majs longe seria cair nas armadilhas do subjetivigmo, $e$

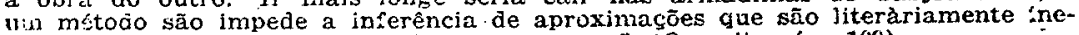
fáveis, rias cujo laço temporal nos escapa..." (Op. cit. pág. 109 ).

(54). - Aliás, sem querarmos ter a pretensāo de toniar partido no problema da preceléncia de uma ou outra poesia, parece-nos que há, na IV fcloga, uma i.tsságem especiulmente destinada aos que, não vendo o fim das guerras civis, perdian a fé no futuro romano; tratu-se dos versos 13 e 14: "Se persistem inda aljuns tracos de nossa jerversidude, êles serão sem efeito e as ierras serāo libcrtadas do terror perpétuo". Cf. Glover. "Vírgil", págs. 128 e es.. 
"Na verdade, Roma eleva tanto a sua cabeça acima das outras cidades, quanto os ciprestes ultrapassam os arbustos flexiveis $(55)^{\prime \prime}$.

Pensamos, assim, não se poder dizer que Roma foi perdida de vista pelo poeta, e muito menos os destinos romanos, aos quais, ao contrátio, é prometido um novo e belo período, uma vez que "a Idade do Ouro é imediata e vai reflorescer sôbre as terras da Itália (56)." Caso completamente diferente encontramos em Horácio que, desesperado da obtenção da tão desejada paz (57), assim principia o seu epodo, dirigindo-se aos romanos:

"Eis que ainda uma idade é macerada pelas guerras civis. Roma sucumbe sob seu próprios golpes. Muito forte para que tenham podido vencêtla nem seus vizinhos, os Marsos, nem as ameaças dos bandos etruscos de Porsena, nem a emolução valorosa de Cápua, nem o cruel Espártaco, nem o Alóbroge traidor à revolução, nem os filhos de olhos azuis da orgulhosa Germânia, nem Anibal, execração das máes, nós próprios consumaremos sua ruína, geração impia de um sangue votado à maldição. E as feras retomarão posse de seu território".

"Ail o bárbaro acampará como vencedor sôbre seus restos fumegantes e a cavalaria flagelará com casco sonoro o logar da cidade. As reliquias de Rómulo arrancadas à scmbra em que estão abrigadas, ó espetáculo sacrilego! o insolente as dispersará aos ventos e à luz do dia (58)".

A êstes tão desanimados versos em que se prognosticam de maneira tão evidiente a queda e a destruição de Roma, segue-se um apêlo ao povo, ou $\longrightarrow$ que achamos muito significativo, uma vez que pode ser tomado como indício de que tais preocupações não eram próprias a todo o povo, mas apenas a uma elite, - à sua melhor parte (59), afim de que esta procure um remédio aos males da época, por um processo radical: o abandôno da cidade, decisão que só deveria ser revcgada mediante a realização de uma série de condiçōes impossíveis, passagem em que o poeta lança mão de um típico exemplo do que, na retórica grega, tinha o nome de "adynata" (60). Em seguida, caberia a esta elite a procura da Idade de Ouro, cujas características seriam parcialmente semelhan-

(55). - Eucúlicas. I, 25-20; Cf. Carcopino, op. cit., pág. 162.

(56). - Olivier, "Les epoues d'Horace", pág. 78 ; Villeneuve, trad. das odes e Epodos, pag. sat, nota I. Cf., contra, Jeanmaire, "Le messianisme de Virgile". pág. 78, 115 e ss.: Hubaux, "Les grands mythes de Rome", pág. 33.

(5). - Para Jeanmare teria sido justamente a ruptura da Paz de Brindes que determinara a composição do cpodo. Notemos, cntretanto. que éste caráter de desespéro não foi tomado a sério por Kukula ("Fönìsche Säkularpoesie", pag. t $t$ ss.). que viu no $2 \mathrm{VI}$ epodo tama verdadeira ironia. Olivier (op. cit.. pás. si e ss.), combatendo éte ponto de vista, apoia-se em Sellar ("The fioman foets of the Augustan age - Horace and the elegiac poets", pax. I3). opinanjo a seguir que tal é o que pensan "todos os que têm orelhas para ouvir" (pag. 93 , nota 1 ).

(55). - XYl ejodo. 7-14. Cf. Stme, "The Roman Revolution", pag. 218.

(54). - Cf. versos $35-37$.

(60). - Olirier, of. cit., pág. 79 ; Cf. Dutoit, "Le thème de l'adynation dans lia poésie antique", păgs. 85 e 86. 
tes às descritas por Virgílio na IV écloga (61), mas que só poderia ser encontrada fora de Rome; naturalmente; estaria ela em certas ilhas maravilhosas, situadas no Oceano (62), reservadas por Júpiter para a "geração dos homens piedosos, quando ao ouro puro das antigas idades misturou êle o bronze. Depois do bronze duro veio o endurecimento pior dos séculos de ferro, dos quais podem evadir-se os homens piedosos, se escutarem o meu oráculo (63)", conforme nos diz o próprio poeta.

Acreditamos ser clara, dispensando portanto qualquer digressão a respeito, a crença do poeta na nova Idade do Ouro, da qual não só Roma estaria excluida, mas ainda mais, para cuja realização seria necessária a mcrte da cidade, abandonada pela melhor parte de seus cidadãcs. Na melhor das hipóteses, tudo isto poderia constituir uma fantasia para significar que os elementos ajuizados da população deviam desinteressar-se dos negócios políticos e confinar-se ao domínio do seu "eu" (64). Tal ponto de vista, que, aliás, resultaria também, por fim, na queda da cidade, não é o que merece $\circ$ apôio da maioria dos intérpreses, uma vez que, reconhrecendo-se de fato um alheiamento do poeta às facçōes em jo. go (65), não se deixa também de ver, na sua proposta, uma versão da tentativa de abandôno de Roma pelos plebeus na época de Camilo (66). E, assim sendo, não há dúvida possível; trata-se mesmo do abandóno e da ruína materiais da cidade, ccm o fito de buscar noutra parte a tranquilidade que Roma não pudera dar aos seus cidadãos.

Tanto para o otimista Virgílio como para o pessimista Horácio há uma preocupação dominante, esta indiscutivel, porque resulta da própria evidência dos téxtos: a da paz (67). Aliàs, a época em que foram compostas as duas poesies em questão, entrє

(61). - XVI epodo, rv. 41 e ss.; If étoga, vv. 39 e ss..

(62). - As aventuras de Sertório nas ilhas Pitiusas e a obra de Posidonio de Apaníla sobre o Oceano scriam as fontes de Horácio a respeito destas afortunadas ilhas. Cf. Jeanmaire, "Le niessianisme de Virgile" pág. 82 e "ti., Hubaux, "Les grands mithes de Rome", pág. 36, Wendland, "H.R.K.", pág. 133̈, n. 4, Villeneuve, trad. Odes e Epodios, pág. 226, n. 1. Poderia ter havido t..mbem a influência de Hesfodo ("Os Trabuhos e os dius". 126-173); cf. Jeanmaire, op. cit., pág. S0, Villentuie, op. cit., pág. 170, n. 1. Ainda, a regpeito te Horúcio, ina a questâo das influencias judias, indo Zielingki ("Iudaei Foratiani", "Los", XXX, 19卂7, pág. is, ap. Carcojino, op. cil., pág. 72, ao ponto de imaginar o poeta misturado aos judeus de Roma. Olivier nega tais relaçes dc maneira absoluta, io mesmo tempo que năo ousa fázelo em relagăo à IV fcloga iup. cit., pág. 76 , n. 1).

(63). - Vv. 68 e sE.:

(64) - Barvick, "Zur tnterpretation und Cluronologie der 4. Fkloge des vergil uis der 16. und 7. Epode des Horuz". in "Philologus", Leipzig, 1943. páts. 28-67, ap. Marolizeau. "L'Année Philologique". XV1, pág. 139.

(65). - Sellar. "The Roman poets of the Augustan age - Horace and the elcziac poets" pás. 123.

(66). - Cr. Hubaux, op. cit., páf. 36; Fuchs, "Der geistige Widerstand geren Rom in der antiken Welt", ap. Thegenbogen, in "Historische Zeitschrift", Bd. 161. Heft 2, 1340 , pas. 333 .

(67). - Ainda nas Bucólicas, tódas compostas entre 43 e 37 a. C. (Pi. chon. -Histoire de la litterature latilse", pág. 327 , nota 1 , ha trechos que renetem a ensia do poeta pela paz. como, por exmplo, $\mathrm{a}$ (do ano 42 ), $\mathrm{v}$. 60-61 e a VI (do ano 39), vv. 3 s8.; cr. "Encida", VI, 847-853. 
os anos 41 e 39 (68), era de molde a colocar em foco a questão fundamental para os contemporâneos, do fim das lutas sustentadas pelos romanos; a desilusão pessoal provocada pelo infeliz resultado de sua aventura política do ano 42 (69), a guerra de Perusa e a intranqüifidade reinante $(70)$, poderiam perfeitamente ter determinado o desespêro refletido no XVI epodo, e a paz de Brindes, dando origem - pelo menos momentâneamente - a uma atmosfera de alegria e de confiança em tôda a Itália, seria o grande fato que serviria de chave para a fixação da data da IV écloga, que não poderia ser explicada fora dela (71). Assim, Horácio, ansiando pela paz, pregaria a sua busca em outras terras, ao passo que Virgilio confiaria na sua obtenção sem necessidade do recurso à èmigração; mas o ideal comum aos dois poetas constituiria sempre o traço básico da Idade do Ouro, por ambos cantada e prevista.

Ora, os acontecimentos políticos que assinalaram os anos seguintes ao de 39 e que culminaram corn a unificação dos territórios dominados pelos romanos nas mãos de Otaviano, que ccnseguira acabar com as Iutas civis em 31 a. C., foram de molde a fortalecer o ponto de vista otimista, expendido por Virgilio na IV écloga; a paz fôra instaurada no Mediterrâneo, e o fôra graças a Otaviano, representando Roma, contra Antônio, submetido aos planos orientais de Cleópatra (72), e que arcava com a pesada acusação de pretender transferir a dignidade de capital, de Roma para Alexandria (73). O vencedor, que conhecia muito bem o estado de ânimo dominante entre a população romana (74), con-

(68). - Para a major parte dos autores consultados, como Carcopino, Villerfeuve, Cartault, Seliar, Olivier, a IV ecloga foi posterior à Paz de Brindes. estando ligaria a este acontecimento; contra esta opinião podem ser citados Eoll, Wicinreich, Weber, Jeanmaire e Vorden (aj. Carcopino, op. cit., pag. 108. nota 2): Quantu ao XV1 epods. Villeneuve situa-o em 41; Kiessling, Sellar, Sudhaus e Olivier, no inficio de 40 ; Jeanmaire coloca-o também nesta epoca, deixando para a IV écloga o ano 41.

(69). - CR. Villeneuve, op. cit., pág. XIII; Carm, IJ, 7, cf. Rostagni, op. cit., pug. 324 .

(70). - Olivier, op. cit., pág. 78, nota 2 ; Jeanmaire, op. cit., pág. 65-66, 'embra tambem a existencia do perigo parta, com Pacorus.

(71). - Carcopino, op. cit., pug. 133; cf. Nock, in "Cambridge Ancient History" \&, pág. 472.

(72) - Horácio, En. IX, 11-16; Od., I, 37; III, 4. Na obra de Propércio, I. VI, 29 há também reflexos déste fato; cf. Sellar op. cit., págs. 321-322; Pvchar. "Augustus", págs. 107-119; Meyer, "Römischer Staat und StaatsgedanHe", págs. 327-328.

(73). - Diāo Cassio, L, 4. Tarn e Charlesworth, in "Cambridge. Ancient History", $X$, pág. fit; Homo, "Le Haut-Empire", pág. 16.

(74). - Cf. o apein de Virfilio, nas "Georgicas", I, 498 e ss.. Lembremos rqui a interessante passagern en que Iuchan destací a importancia do aspecto moral da missāo de Augusto: "Tive decadence of the Republic and the years of uar had produced a kind of listlessness, not unlike the mediaeval "accidie". "nich was porlaps a gravated by the increase of malaria through a jong-con: timued neslect of public hyriene. There seemed to be a decline of intellectuai ind spiritual energy, as if old age had come upon. The readiness with which the principute was accepted made its first stage easy, but the second stage was the more difficult because of this very docility, for the impulse to revolt is $a$ proof of iffe in the body pulitic. Tlere was little hope for Rome if its spirit became tiat of the common epitaph for slaves? "I was not. I was. I shall not be. I do not care". To revive the soul of the Roman people, and to put one into the cmpire at large, were the most delicate tasks which Augustus had to face". ("Augustus", pags. 250-260). 
siderou a restauração da paz como uma verdadeira missão que the fôra imposta pelas circunstâncias e cujo preenchimento seria a condição indispensável da perduração do seu poder (75).

O que é-muito importante para o nosso caso é que Augusto não se desligava da idéia de Roma que - aliás - era muito importante para êle, por the permitir unificar, num só ideal, tanto o novo regime do Império nascente como as pretenções ao "Imperium mundi" e a própria pessoa do Imperador (76). Compreende-se perfeitamente, partindo daí, a associação da Dea Roma ao culto imperial (77).

Tưo isto dava à IV écloga a opcrtunidade para a primeira de suas adaptações: a Idade do Ouro estaria de volta graças ao advento de Augusto, o Imperador seria o "Weltordner" - na expressão de Rehm - representante da Razão Divina, emissária da Paz Universal e da Justiça, o "Pacator Orbis" (78); e da Itália, ainda mais, de Roma, partira o estabelecimento da Idade do Ouro. Justificar-se-ia, assim, que nas "Geórgicas", escritas já depois da ligação de Virgílio ao círculo de Mecenas, se encontrasse uma passagem famosa que pode ser interpretada como uma réplica ao pessimismo expresso no XVI epodo (79) e que retrata bem o júbilo do poeta pela realização de seus ideais de paz. Atribuindo à Itália características próprias à Idade do Ouro (80), Virgilio saúda-a, por fim, ccmo "terra de Saturno (81)", fecunda em colheitas e em heróis; e, por certo, tinha êle em mente o verso 5 da IV écloga: "Eis que volta a virgem, e que volta o reino de Saturno". Notemos, de passagem, que não era difícil ligarem-se, neste único verso, a Itália e Augusto, conforme nos mostra Carcopino (82), lembran-

(75). - Rostovtzeff. "Historia social y económica del Imperio Romano", I, pág. 6\%; Hahn, "Das Kajsertum", pág. 6; Meyer, "Ilömischer Staat und Staatssedanke", pás. 330. Note-se, aliás, a importância đ̣o fechamento do altar de Jano, efetuado por Otaviano, pela primeira vez, em 29 a.C.: cf. "Res Gestae Divi Augusti", 13; Suetónio, "Augusto", 22; Tito Livio, I, 19, 3.

(76). - Fiehm, "Der Untergang Roms". púg. 14.

(7i). - Sóbre a Dea Poma, cf. Maynial, art. "Roma", in Daremberg \& Saglio, op. cit...

(78). - Fehm. op. cit., pág. 14 ; cf. "Bucólicas". I, em que o instaurador da paz surge como sendo un deus (Glover, "Virgil", pág. 155).

(74). -- Jeanmaire, "Le messianime de Virgile", pág. 92.

(80). - 1., 143-144; 149.e ss.. Cf. Grenier, "Le génie Romain". págs. 258 e 300: Gernenz. "Laudes Romae", pág. 20.

(81). - II, 173; cf. Giover. "Virgil", pag. 112; Cochrane, "Cristianismo y rultura vasica". pags. $33-75$ : "Assim Virgllio proclama, pela primeira vez, a autonomia do espfrito ocidental..." A base da-civilizaçäo ocidental era assim, en certo sentido, local e racial: seu lar, a Itálla, seu "material", a pura e não viciada estirpe jtaliana..."

(52). - Op. cit., pág. 197. Trata-se das "Geórgicas", 1, 32-34 (vens tu, novo astro do verão, junta-te aos que conduzem nossos longos meses, e estara o teu Jugtr entre a virgem e o Lscorpião?), a respeito do que assim se expressa Carcopino: "Nenhuma zona do Zodiaco poderia melhor convir ao principe que, niscido em 6.3 a.C. na manhá de 23 de setembro, tinha vindo a Terra no cruzamento indeciso de Erizona, isto $e$, da Virgem, donde o Sol acabava de aair, e das Pinças, jsto é, da Falança, em que então estava entrando. Atribuindo-o ao seu hicroi, Tirǵlio inclinava retrospectivamente o verso 6 de sua ecloga diante de Otávio... o hoinem por quen a Idade de Ouro seria efetivamente restabelecida entre os romanos". 
do ainda outro trechó das "Geórgicas", teferente a Augusto, e a existência da mesma ligação na "Eneida":

"Mas eis aqui, eis o herói que te foi tão freqüentemente prometido. César Augusto, do sangue dos deuses, que restaurará a Idade do Outro no Lácio e nos campos em que outrora reinou Saturno (83).".

Quanto a Horácio, vêmo-lo atraido também por Mecenas, a quem foi apresentado por Virgílio e Vário em 39-38 (84), e abandonando, na sua obra, o tom de desespêro do XVI epodo. Contituando sua produção literárie, dedicou-se êle primeiramente às "Sátiras" (livio I em 35, II em 29), e só com o IX epodo e com as odes - cujos livics I, II e III foram compostos no ano 23 a. C. (85) - podemos avaliar os seus sentimentos e opiniöes em relação ao futuro de Roma.

Dentro da variedade de assuntos tratados nestas poesias, enccntram-se as odes cívicas, algumas das quais revelam-nos que 0 poeta deixoa de ser o pessimista do XVI epodo, ligando-se a Virgílio no culto a Roma e na crença no futuro da cidade. Naturalmente, a mudança de posição devia-se à realização do grande objetivo de que Horácio outrora desesperara: a paz, que Roma acabara por impor ao mundo mediterrâneo (86). E o IX epodo, que foi certamente escrito logo após a chegada a Roma da primeira noticia da batalha de Actium, e que se inicia por uma saudação ao vencedor, põe em relêvo a alegria do Horácio,..."ligado, e para sempre, ao parido encarnado por César, e que era o dos deuses, da paz, da ordem, da dignidade (87)." E esta poesia que pode ser oposta ao XVI epodo, permitindo que se veja como o poeta, partirndo da descrença, chegou à confiança e até mesmo 20 entusias-

(A3). - "Eneida". Th. 792-795; cf. "Bardon. "Les enpereurs et les lettres tatines". pag. 74; Buchan. "Ausustus". pag. 172; Grenier, op. cit., pág. 379; Jedurnatre. "Ise messianiane de virgile". pag. 93 . "It is this great longing for Pcace on Farth after the tribulation of a "Time of Troubles" that has moved the subjects of the founders or preservers of the universal states to venersite them as Baviotars of Society or actually to worship them as gods incernate (Tuynbee. "A Study of History". TI, jeg. 6). Note-se a importáncia da. mencto de Sufumo: "Saturna rena, aurea saccula, quia Saturnus aurec Necule regnasse dicitur" (Deutero Servius, y. 5. p. 45 Thilo, ap. Carcopino. op. ctt, jig. 39). "Eneida", VIIT, 324 (cf. Glover, "Virgil". pás. 158).

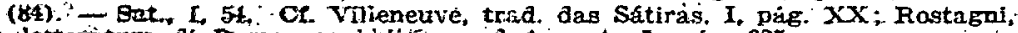

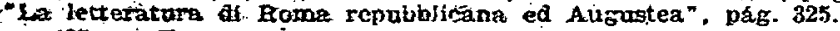

(85). - Rorgtagni: os: cit., pấ. 333.

(\$A). - Fm expressixa pasaagem Grenter chame a atençäo para a magniturk to uroblema da pan nesta época. ajudando-nos a compreender, tanto o de"orspero. como o júbilo. de Hórácio: "Mieux que jumaís, aufourd hui, nous pouFons comprendre l'exilitation des peuples devant l'espoir d'un tel changement. Les guerres, tontes les suerres, sont definitivement terminees; il $n^{*}$ est plus dennemie vaincre au' dehors; dans d'empire, la sagesse, la modération, la piété, nswareront la concorde. Si cruellement decus quaient ete de tels espoirs, cette idé de la paix romafne Étendant son bienfait sur lè monde apparait rraiment comme "uine grande et noble conception", (op. cit., paf. 355). Cf. Howald, "Die

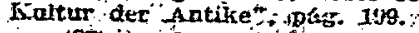

it (87) : Olivier, óp. cit.; pag. 100 . 
mo, na expressão de Olivier (88), revelando o que se pode chamar a sua conversão política. Conversão esta que o aproximava de Virgílio, unindo os nos sentimentos de admiração pela $\mathrm{Pax}$ Augusta e no vaticínio de grandes destinos à cidade que, em breve, seria chamada "Urbs AEterna".

Como Virgilio, Horácio terá também a sua Roma Ideal, glorificada na sua imaginação; e desta Roma, Augusto, gradualmente, tornar-se-á o representante (89), estando sempre ligado à idéia de paz, que o poeta nunca deixará de relembrar. No primeiro livro das Odes enconiramos, assim, a II, em que Otaviano, assimilado a Mercúrio, é invocado para vir em socôrro do "império desmoronante (90)", e a assimilação é significativa, porquanto Mercúrio simbolizava aqui o papel pacificador de Otaviano, por ser também o deus da persuasão (91). O terceiro livro das Odes é, dentre os quatro, o mais importante para nós, e principia por uma série de poesias que fazem de Horácio "o poeta de Roma e da vida nacional restaurada sob as condiçōes do novo Império (92)." Destaquemos a ode III, em que se lê a predição das glórias de Roma, predição esta feita pela deusa Juno, e na qual se nota, se não uma expressa menção de eternidade, pelo menos a garantia de um domínio universal e de lenga estabilidade (93), desde que os romanos respeitassem sempre a condição de năo procurar restaurar o caráter asiático dos fundadores lendários da cidade, provenientes de Tróia; deveriam, ao contrário, manter para sempre o caráter italiano de Roma (94). Ora, é manifesto o abandôno das idéias emigratórias do XVI epodo, e se aproximarmos tal Ode à "Eneida", XII, 827 (95), concluiremos, então, pela vitória completa do ponto de vista romano e italiano de Virgílio, sôbre o de Horácio, que sonhara com a Idade do Ouro nas Ithas maravilhosas do Oceano, mas que acabou por ligar-se ao seu confrade, no entusiasmo pela Itália e pela cidade de Roma.

No ano 17 verificaram-se os Jogos Securares, celebrados por Augusto com a intenção de festejar o início cie am novo século para Roma; o momento era propício, porquanto a opinião públi-

(88). - Ibidem, pág. 110.

(89). - Sellar, op. cit., pág. 150. Notemos, entretanto, que se deve fazer uma diferença entre a admiração pela obra de Augusto e pela sua pessọa, como nos diz Fardon, op. cit., pág. 83: "admiration pour l'oeuvre du prince, - antipathie, ou tout au moins médiocre sympathie, pour l'homme qui veut utiliser sa poésie à des fins politiques".

(90). - Vv. 43 e 25-26. O mesmo tema de norror as guerras civis é tomado $\in$ I, 14, e para a abertura do livro II.

(91). - Vllieneuve, trad. Odes e Epodos, púg. 9 das Odes, nota 7.

(92). - Sellar, op. cit., jág. 154.

(93). - Vv. 38-39 e ss., 57 e - as.

(94). - Possível alusão ao projeto de César de transportar para Troia a -apita! do Império (Seutónio, "Cesar", 79), ou entāo, conselho a Augusto pars que ésté nâo se deixasse tentar pelo" sonho de u'a monarquia divina do tipo oriental (Mackay, "Horace O. III 3, date and interpretation", in "Class. Rev.",

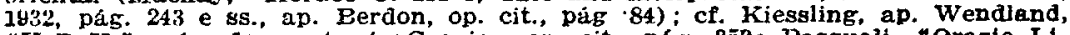
“H.R.K.", pág. 14s, nota 4; Grenier, op. cit., pág. 350; Pasquall, "Orazio Lrico", päg. 680 .

(95). - "Que a raca romana seja possante em virtude do valor italiano". 
ca já havia sido conquistada pela grande obra de pacificação e nela Augusto podia encontrar eco para as festividades que eram destinadas a proclamar, pomposamente, a abertura de uma éra meThor do que fôra a que terminara com o fim das guerras civis (96). Virgílio E Horácio encontraram-se então, ambos ligados nas esperanças e no entusiasmo pela cidade imperial e pelo realizador da paz (97); apenas, Virgílio, que nạao póde ver os jogos do ano 17 a. C. inaugurando a nova éra, neles colaborara com uma antecipação de mais de 20 anos, com a sua IV écloga (98), ao passo que Hiorácio teria uma participação imediata, encarregado que seria de compor o hino oficial que, cantado por um côro de jovens romanas, abrilhantaria as solenidades do terceiro e último dia dos Jogos Seculares. A glória de Roma era aí exaltada, demonstrando-nos a tendência do poeta a desejar a duração da cidade, num fastígío perene, como se vê pelos seguintes versos:

"Sol nutridor, que sôbre teu carro brilhante fazes surgir o dia $e$ o escondes, que renasces novo $e$ igual, possas tu nada de maior visitar do que a cidade de Roma! (99)".

Naturalmente, Augusto e sua políica são também objeto de grandes louvores e, como era de se esperar; a paz está entre os grandes beneficios que, graças ao principe (êle próprio de origem divina), os deuses restituem a Roma (100).

O IV livro das Odes, composto após o ano 17, liga-se, então, completamente a Augusto, e aí vamos ainda encontrar o tema da paz, como, por exemplo, na ode $\mathrm{V}$ e, particularmente, na $\mathrm{XV}$, que encerra o referido livro. Nesta composição Horácio parece ter querido por em evidência o tema principal de sua poesia, o' inestimável benefício que os rcmanos deviam to Príncipe: a restauração da paz. Assim, após ter cantado, nas odes IV e XIV as vitórias obtidas na época de Augusto, principia êle a ửe XV com versos que nos lembram, de maneira bastante significativa, 0 trecho inicial da VI bucólica de Virgílio:

"Como eu quizesse contar os combates $e$ as cidades conquistadas. Febo advertiu-me, fazendo vibrar a sua lira, de não desenrolar minhas pequenas velas no meio das ondas tirrenianas. Tua éra, ó César, féz renascer nos campos. as messes abundantes, entregou ao nosso Jupiter as insignias arrancadas nas portas orgulhosas dos partas, fechou o templo. livre, de guerras, de Jano Quiriniano..."

(a). - Villeneure, trad. Odes e Epodos, hág. XXXIX-Xl; Rostovtzeff, op.

4it. I. pag. Ilf: Marquardt. "Le culte chez les liomairs", 11, pag. 82.

(19). - Insquali, op. cit. pát. 737 .

(4b). - Hild, art. "Saeculares Ludi", in Daremberg \& Saglio, op. cit.; para

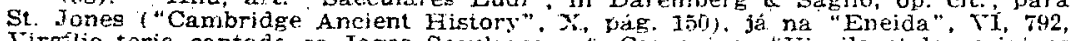
Tirgilio teria cantado os Jogos Seculares; c1. Carcopino, "Virgile et les origines j'Ostie". pág. 728.

(98). - Vv. $9-12$.

(100). - Vy. $49+58$. . 
Além disso, a repetição de tais louvores na Epistola I do 1ivro II (101) confirmaria as idéias de Horácio e êste respeito e revelaria ainda mais o abandôno do desânimo expresso no XVI epodo.

Detivemcs-nos em Virgílio e Horácio por 'serem os mais significativos representates dos ideais que - no momento - constituem o nosso objetivo. Mas basta. uma pequena vista d'olhos às obras de outros autcres, bem como a referência a certos testemunhos arqueológicos, para que se verifique quão difuso era o lema da paz entre os contemporâneos.

Tíbulo, que não pertencia ao círculo de Mecenas e que não apresenta na sua obra tendência a louvar Augusto (102), canta a paz (103), manifesta sua aversão pelo serviço das armas (104) e, não fugindo à linha de Virgílio - sob cuja influência se colocara - dá expansão ao seu entusiasmo pela missão de Roma (105) e torna-se um dos responsáveis pela própria expressão "Urbs AEterna".

Ovídio, mesmo carregando consigo a pecha de exagerado servilismo em relação ao Príncipe (106), não pode deixar de ser lembrado, porquanto deixou-nos passagens famosas como, por exemplo, a invccação à paz nos "Fastos" (107), e deu origem 80 conceito da eternidade do Imperador, mas ligada à do Império e, portanto, à da própria Roma (108).

Quanto aos documentos arqueológicos, lembremos apenas dois, que são os de maior importância: a Ara Pacis - (109) e o altar chamado da Gens Augusta, descoberto em Cariago (110).

Ora, tudo o que acabamos de dizer sôbre Augusto e a paz era de enorme importância na época, porquanto valia como uma verdadeira réplica às diversas prediçôes a respeito da queda de Roma, tanto locais como de origem oriental. E relembremos ainda que, se Augusto era tão celebrado, êle mesmo fazia questão de as-

(101.). - Vv. 250 è ss. .

(102). - Sellar, op. cit., pag. 242, 244; Bardon, op. cit., págs. 97-8.

(103). - I, 10, 45 e ss.; cr. Ferrero, "Grandeza y decadencia de Roma", $v$, jisgs. $60 \mathrm{C}$ sis.

(104). - I, 1, 58; I, 2, 65: I, 10, 33 .

(105). - II, 5 ; cf. v. 57 ; "Roma, os deztinos te chamam para reinar aobrc a terra".

(1(6). - Bardon. op. cit., pags: 93-94.

(107). - 709 e ss..

(108). - Fastos, 3, 421; Tristius, 5, 2, 45 e ss.: Metamorfoses," 15, 836.

(109). - Cf. "Res Gestae Divi Augusti", 12. Turchi. "La religione di Roma antica". pags. 223 e ss. : Charbonneaux, "L'art au siccle d'Auguste" pág. 66 e 89. (110). - Cf. Rostoitzeff, op. cit., I, pág. 104 e lämina VI; Charbonneaux. op. cit., pág. 74 e ss.. 
sociar o seu culto ao da Dea Roma, surgindo assim a cidade divinizada como um lezítimo símbolo da paz e do Bem no mundo mediterrâneo.

Havia, entretantc, necessidade de liquidar ainda com outra das crenças da época, a fim de que tal papel benéfico pudesse ser ligado a Roma, sem qualquer obstáculo. Tratava-se da mesma questão das contínuas lutas civis, que havia acabado por gerar a ¿déia de que Roms, sofria porque pecara, constituindo as convulsões internas o seu pesado castigo. Já tocamos ligeiramente neste aspecto de nosso tema, e que se acha tão bem refletido no VII epodo de Horácio, composto em 38 a. C.:

"Jamais, na suá ferocidade, nem os lobos nem os leões se enTureceram assim, a näo ser contra uma espécie diferente. Tratase de un furor cego, de uma fôrça irresistivel que vos impele, de um movimento culpavel? Respondei. - Eles calam-se, uma palide z macilenta tira as côres aos seus rostos, suas almas transtor nadas ficam en estupor. Então é verdade: amargos destinos perseguem sóbre os romanos o assasinio impio de um irmão, desde - dia em que o sangue inocente de Remo correu sôbre a terra, para maldição de seus sobrinhos (111)."

Na obra de Virgílio encontramos expressa a mesma idéia, quando o poếa invcca melancòlicamente os deuses, nos seguintes versos:

"Rômulo, Vestá, que velai sôbre o Tibre toscano e sôbre as palácios de Roma, não impedi éste herói de vir em auxilio déste século em ruinas; muito. e durante muito tempo, nós já expiamos os perjúrios de Tróia e da raça de Laomedonte (112)."

Como se vê, Roma aparecia também como uma cidade amaldiçoada, o que, aliás, enquadrava-se perfeitamente no cenário geral da época, plena de consciéncia de culpa, de necessidade de salvação, de cismares místicos, de inclinações espiritis‘as e ocultistas (113); sua purificação tornava-se então necessária, para que, com

(111). - Vv. 11 Es.

(112). - "Georgicas". I. 496 e RS. Jennmeire vé também na TV écloga a crença de virgilio em majuicues cujos fiejtos deverian desaparecer para que yudesse ser instaurada a lade de ouro: "Lre moete semble avoir trouvé quel-. que part. ou peut-ütre dans sa pöpre sensibilité, la doctrine d'une triple malédiction attachés à l'humanit comme suite de coulpe ancienne; le mal et la

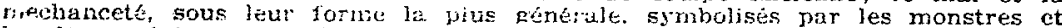
les étres vénimewx. - la. Euerre. - le travail. L'ake d'or sera revenu quand ins effets de ces trois mátedictions auront disparu. Le mal dans la nature, Ja perfidie des poisons, lit ruse du serpent, la fercicie du lion, tout ce qui est probablement le triste herritage ac lage de fer disparait dabord par le "ctour de la nature as l'imnocence" ("Le rressianisine de Virgile", pág. I06). E lagsange $\dot{\epsilon}$ de oriniăo que, nesmo na 3 ecloga, tratid-se também de um crime "propre aux hommes de son temps... Le béche ne sera ancien qu'au moment ou deja les hommes sont presque revenus à l'innocence. Aujour-d'hui encore, hier da moins, il débordait et cxercait ses ravages; c'est toute la corruption de l'aze de fer, de l'age ou fome se debattait dans les zuerres lciviles, et ces usurpateurs dont le jucte avajt th tant a souffrir". "Le prétendi messianisme de Virgile", pág. jiss)

(113). - Wendand, "E.R.K.", pút. 740. 
- estabelecimento da Pax Augusta, pudesse ela surgir como uma entidade benéfica, em condições de reagir com vantagem aos pessimistas e aos vaticínios de procedências judia, que antegozavam a sua queda próxima, com o castigo pelos males que ela já causara aos povos dominados.

A purificação, naturalmente, exigia um purificador, um salvador, e isto numa épcca em que tais idéias estavam em plena efervescência, uma vez que, no Egito, esperava-se um "Grande Rei", que deveria exercer durantè longo tempo domínio sôbre tôda a terra; no solo do Parsismo voltavam-se es esperanças para o Saoschyant, que deveria nascer de uma virgem e ao qual caberia libertar a terra da instabilidade e da morte (114); e entre os judeus, conforme nos dão testemunho os salmos de Salomão e os oráculos sibilinos, as atençõts prendiam-se também à vinda do Messias (115) que se caracterizaria pelo seu papel "de grande pacificador e de restaurador da ordem e da harmonia perturbadas pelos homens. Nada mais natural, portanto, que, em meio à :alegria reinante com o fim das guerras civis, Otaviano surgisse como um candidato à encernação do salvadcr, dando margem, assim, a que a IV écloga - cuja plasticidade prestava-se tão bem às adatações de circunstância - pudesse ser interpretada como uma composição messiânica, não importando agora se. isto concordaria ou não com o que tivera o poeta em mente quando a escrevera. Os escoliastas, para os quais o poeta cantava aí simplesmente o renascimento do mundo sob os céseres, sem dar atenção alguma a questōes de cronologia, mostram-nos que se acreditava estar em Otaviano-Augusto a personificação da criança da bucólica (116).

Tal adatação justificava-se bem, nas vésperas do solene momento em que Otaviano, adotando o cognome de. Augusto, como que determinava o esquecimento de tôda a sua carreira política anterior, muitas vêzes manchada por atos inescrupulosos e sangrentos, e apagava a origem revolucionária de seu poder para deixar apenas em evidência o grande benefício por êle feito a Roma, de restituir-the a paz e a ordem (117). - E não era algo de semelhante que se fazia necessário à própria Roma? - Por acaso não fôra a história da cidade, nas suas linhas gerais, parecida com a carreira política de Otaviano-Augusto? - As inúmeras guerras de conquista, orientadas por uma política que freqüentemente podia ser qualificada como primando pela falta de boa-fé, comparavam-se às lutas do pacificador para: chegar ao poder; como êste sentira a necessidade de apagar o seu agitado e inescrupuloso passado, assim

(114). - Guntermann, "Die Eschatologie des IHl. Paulus", pág. 2; cf. Bousset. "Die Religion", pig. 203; Murray, "Stoic, Christian and Humanist", pags. 66-67.

(115). - Salmos, XVII, 21 e ss.; Or., III, 652-658; Cf. Lagrange, "Le Judaisme avant Jésus-Christ", pág. 152 e ss. e pág. mo8.

(116). - Escoliasta de Eierna, ad. Iscl. IV, fr. p. 775 , ap. Carcopino, op. cit, Frig. 200.

(117). - Cl. Wendiand, “E.I.K.”, pág. 143. 
Roma também o sentia, uma vez que vivia sob a convicção do pecado, agravada ainda pela corrupção de costumes. Ela atingira o objetivo que se propuzera, e o fim parecia bom; mas a memória dos meios empregados não havia passado, $e$ isto levava os homens a desejarem um retôrno à moral e à fé de tempos mais antigos $e$ mais puros. Os males do presente eram a conseqüência de um longo afastamento da retidão e da piedade (118), e ainda Horácio serve de porta-voz dêste sentimento, dirigindo-se à geração nova de sua época:

"Tu expiarás, inocente, as faltas de teus ancestrais, Romanc, enquanto não tiveres restaurado os templos, as moradas desmoronantes dos deuses e suas imagens que estão manchadas por uma negra fumaça (119)."

"Pouco faltow para que ela perecesse, a Cidade, entregue às sediçóes, destruida pelo dácio e pelo etiope, éste formidável por sua frota, aquele superior no lançamento das flechas."

"Idades fecundas em crimes corromperam inicialmente casamentos, raça, familia: desta fonte brotcu o flagelo que se espalhou sôbre a pátria e sôbre o povo (120)."

O sentido dêstes versos é perfeitamente claro: os males de que Roma sofria nāo seriam curados, a menos que ela se livrasse da impiedade e da impudicícia que era a sua imediata consequência (121); tratava-se de uma verdadeira ânsia de libertação da culpa e dos pecados, após o início de uma nova era de paz para os romanos (122).

Ligados justamente a tais idéias de pecado, castigo e necessidade de salvação, que tão melancòlicamente se exteriorizavam na literatura da época, temos a considerar dois fatos de grande significação: o da preferéncia de Augusto pelo deus Apolo e o que diz respeito à nova fundação de Roma pelo pacificador.

Suetónio (123) nos diz expressamente que Augusto surgiu como personificação de Apolo num banquete secreto, "chamado comumente o ágape das 12 divindades", e refere-se à crença que dêle fazia um filho de Apolo (124).

(118). - Showerman, "Eternal Rome:" pág. 146.

(119). - Oơs, 111, 6, 1-4.

(120). - Odes, III, (i, 13-20.

(121). - Tilleneuve, trad. Odes e Epodos, pág. 169, n. 3. Cf. Pasquali, op. cit., pags. 7ot-ius.

(122). - Wendland, “H.R. K.", páz. 2ui.

(123). - "Augusto", 70: "os convivas ai apareceram, com efejto, en vestes de deuses ou de delisas, e o proprio Augusto, disfarçado de Apolo...". Para Jeanmaire. tá festim teriá tido lugar ent fins do ano 41. "Le messianisme de VirFile", paig. 5H).

(121). - "Augusto". 94: "Nas coleçües "de axenturas divinas" de Asclepíales de Mendes mcontiv a seguinte historia. Tendo Atia ido, no meio da noite, a Lma cerimónia scienc em honra de Ajpolo, léz colocar a sua liteira no tempio "af adormecea, enquanto as demais untronas volta iam para casa; ora, de repente, una serpente introduzin-se ao seu lado e retirou-se logo depois; ao acor. dar, ela se purificou, coimo se tivesae sádo dos bracos lie seu marido: desce est momento ela teve sobre o corpo u'a mancha stmelhante à forma de uma scrpence. e jarnais conseguiu fazela desaparecer, de tal modo que teve que renunciar para sempre aos banhos públicos; $\epsilon$, que, como Augusto nasceu nove 
Que tal deus tinha as preferências de Augusto, é ponto que perece indiscutível hoje em dia, uma vez que seu culto foi decididamente favorecido durante o seu govêrno (125), estando mesmo ligado à própria vitória de Actium; esta se verificara próximo a um altar de Apolo, e esta circunstância teria contribuido para dar o triunfo aos ocidenteis (126). Entre os templos construídos durante o grande movimento de restauração religiosa, um dos mais importantes foi o de Apolo Palatino (127), e basta que se recorra ao "Carmen Saeculare" para que se perceba a importância que Apolo merece de Horácio, como deus que presidia às solenidades (128), o que deu margem a que Warde Fowler, "talvez o mais penetrante dos exegetas do "Carmen", assim se expressasse: "Não há dúvida de que fazia parte da política de Augusto colocar o grande Júpiter da república como que no segundo plano, quando comparado com o seu próprio Apolo; isto pode ser provado de muitas manei-

unses dejois, yassou a ser considerado filho de Apolo. Alem disso, antes do dar à luz, Atia viu em sonho suas entranhas que subiam até os astros e descicuravam-se sókre tóda a extensão do céu e da terra. Por seu lado, Otúvio, o pai de Augusto, sonhou que do seio de sua mulher saiam os raios do Sol". Cf. Jeanmaire, "Le inessianisme de Virgile", pág. 161. nota 1. Nião faltou também quem adaptasse Augusto ao verso 10 da IV ecloga, como se vê pelas escón llas de Servius. "Há os que neste verso Casta, fave, Lueina; tuus jam regnat Ajullo, afirmam estar representada Otávia, irmā de Augusto e, do mesmo modo, : $r$ Tugusto o deus Apolo." (ap. Jeannaire, "Le nessianisme de Virgile", pág. Fif. Lembinos, entretanto, a grande dificuldade que apresenta o verso 10 , 0 que leva Jeanmaire a dizer que se trata da mais obscura passagem de um texto que abriza tintos enigmas (ojs. cit., pág. 53j; cf. Reinuch, "Cultes, Mythes et Feligions", 3I, jág. 71: Lagrange, "Le prétendu messianisme de Virgile", pág. 5i:; Guinebert, "La politique religieuse de flome aux deux premiers siecles de l'Fimpire*, paig. 48 .

(125). - Cf. Boissier, "ILa reigion romaine", I, pág. \$0; Piganiol, "Histoire ie Rone", pág. 229; Charbonneaux, op. cil., jág. 9.

(126). - I'ropércio, IVY, 6; alusões na "Ineida", VI, 69-71; VIII, 720. Boissicr, "La religion romaine", I, pág. \&1. Frever, "Weltgeschichte Europas", pág. jis8: *... erst Actium ist der hlare Sieg des Westens uber den Osten, der Sieg römischer virtus über hellenistische Machtenfaltung; der Sieg der römischen Gütier, voran des Ajolton uber die Gottertratzen des Orients..."

(127.). - Cf. Horácio, Odes, I, 31, 1; Propércio, II, 31. Notemos, ainda, que - dia do aniversário de Augusto coincidia com o do templo de Apolo no campo तe Narte, e yue o dia 4 de uutubro, que assinalavia a inauguraçäo do templo de Apolo Palatino, era também consagrado às festas do "Genius Publicus" e da "Fausta Felicitas" (Gagé, "Res Gestae Divi Augusti", pág. 182).

(12s). - Cf. Bucian, “Augustus". págs. 163-174 e, principalmente, 185, da qual destacamos o seguinte: "Above dil he (Horace) stood by the Princeps in his cult of Apollo, the chosen god of tive new humanism. His highest prajse for Augustus is that be is Apollo's servant. it is Apollo, patron of enlightenment and peace, W\%o is chiefly celebrated in the Camen Saeculare, and at the dedication of Augustu's greatest building, the temple of phoebus on the Palatime, Hol ace does not. lise Propertius, gloat over the architectural magnificence. but asks from the god those gifts nhjch Augustus was striving to bring to Rome". rx. Jeanuaire, "I c nessianisme de Virgile", pág. 155: Felrero, op. cit., V, pág.

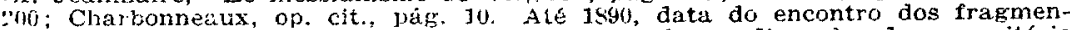
los de inscriçóes relativas aos fogos seculares, nào se dispunha de um critério sólido para medir a preponderáncia de Apolo e de Diana no "Carmen". Foi esta desnoberta que permitiu demonstrar-se que, de natureza semelhante a dos outros deuses. Apolo e Diana surgiam como divindades previlegiadas, as quais ra dericado o dia suprelio dos jogon, e que deviam ouvir em primeiro jugar o hino solene (Gagé, "Tacherciles sur les jeux aéculaires", pág. 27). Nilsson. por sua $\%$. e vastante incisilo a iste respeito: "Die Tradition, der sich Augesius willig fiite, zwang dazu, die briden ersten Tage dem Juppiter rom Capitol und seiner Gemahlin zu Widmen. Die Gotter von der Burg der Republik haben den zeltichen Vortritt, in Wirklichkeit gehör der wichtigere Teil der Feler fem personlichen Schutzgott des liaisfs..." (s. v. saeculares (ludi), in $P$. W.! "Fealencycl.", 1520, col. 1716, ap. Gage. op. loc. cit., nota 2 ), 
ras: não obstante, suspeito um pouco de que Horácio, aqui, foi um tanto além do que the fóra pedido (129)."

Ora, achamos bastante clera a relação entre tal preferência e as idéias expressas, por exemplo, no VII epodo. Tratar-se-ia, a nosso ver, de um verảadeiro esfó-ço de purificação dos pecados cometidos pela cidade de Roma é cujo castigo caira tão pesadamen te sóbre ás geracōos dos últimos tempos da Repúbiica. Apolo, deus das purificaçōes e expiaçc̄es em geral e, particularmente, encarregado da expiação por crimes de sangue (130), limperia a mancha que seguia a história de Roma e que tivera início com o assassínio de Remo $e$, além disso, como verdadeiro mediador para assegurar - paz éntre os deuses e os nomens (13i), Apoio era a divindade indiaada para merecer a predileção do príncipe que resolvera dar irançuiiidiade aos romanos, mal saídos de uma "éra de inquietação e de miséria, com a quil se ligavam a confusão e a necessidade de religiāo, em que os homens sentiam-se oprimiāos por inconscientes e conscientes transgressões das ordens dos deuses. Havia, assim, fundamentos para a influencia de Apcio sôbre as almas. Ele era a autoriàede que resteurava e mantinha a paz com os deuses. Sua missäc não era a de cespertar consriências, mas de acalmá-las. Nâo era um revolucionário religioso, nem mesmo um reformador. Ele construia sóbre um velho alicerce ou, mudando a figura, plantava nevos e impetuosos reibentos em solo velho (132)". Augusto, ligado a Apolo, cesempenharia o papel ce purificador de Roma, daria à cidade a oportunidade de recomeçar sua história, não por um

(19.1) - -The C. S. of Horuce and its periomance" ("Ciassic. Quarterly"

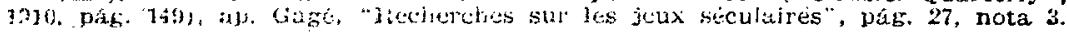
(136). - Cf Horicio, Uties, I, 2, 25-32, tratando do assassinjo de César, em

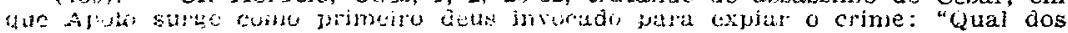

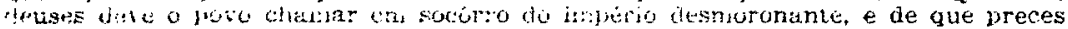

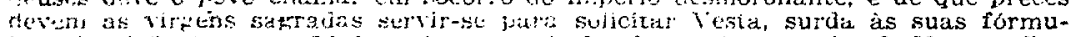

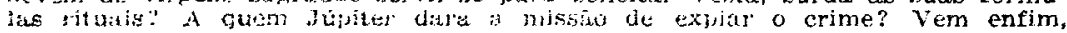

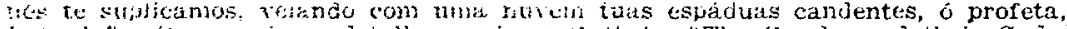

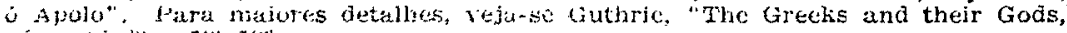

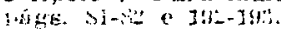

(3a). - Cf. Gage, "Recherenos...". pás. 23: "Notons qu'à lépoque d'Auguste la tendatice de la sinulation theologique est bien de faire d'Apollon un intermidiaire secularable entrc les itommes et le grand Jupiter, dont il reste avant

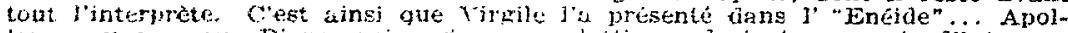
ton - et si pocur Diane, qui partage son detin - devient une sorte dinterces-

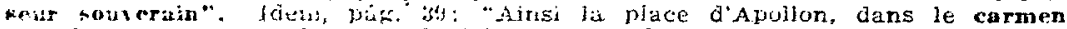

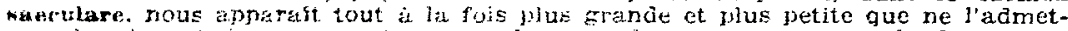
ient lit blapint des commontiatours: pius grande, en ce sens que le dieu y est is fung partout prescnt, et non pas seujement dans les strophes ou il est directement intojue, puiagu'i] $n$ ist pas de priêre à dautres divinites gui ne Juj eoit aussi confle: ninis plus petite, puisqui elle ne jui tst pas raite, conme on le dit trop sourent, aux défens des dieux do Capitoite Dans tout le carmen, comnit a fond oes jewx, Ajollon et Iriane ablaraissent comme des intercesseurs..." (132). - Nisson, "A History of Grteli religion", págs. 199-200. Notemos que as latias transcritas, refursntes to stiulo il a.C., adatam-se perfeitamento nos twitiventos dorinantes na Enoci da Augusto, e frisemos que o próprio Antonio tanbem emuadrou-se nestat ordem de jaeias, ao ter preferéncia por

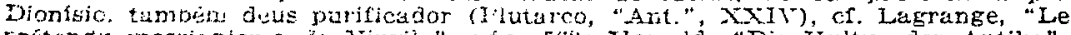
prétendu messiantsne de Tirgile". pã. 56; I jowald. "Die Fultur der Antike". pág. 190: Freyer. "Weltgeschicinte Europas", pas. "43; Jeanmaire; "Le wessianisme do virgile", Dús. 27, 50. 
crime, mas po: um grande benefício: o de patrocinar a paz no mundo mediterrâneo (133).

A relaçäo com Apolo, aliás, segundo Gagé, estaria refletida no próprio cognome de Aügusto: partindo da particular importância da ligação entre a Sibila - cujos oráculos são mencionados no início da segunda estrofe do "Carmen Saeculare" - e Apolo, passa Gagé a afirmar que "a origem sibilina dos jogos seculares destaca-se então plenamente nas cerimônias do terceiro dia, e por ela, - seu sentido apolíneo." Em seguida chama a atenção para o verso 61 do "Carmen" (134), e assim se expressa: "Os comentaristas, em sua maior parte, mostram-se um tanto embaraçados qùando se trata de traduzir o vocabulo augur sob o qual Apolo é invocado no v. 61: Deus profeta? - Seguramente; a tradução não é falsa, mas ela não exprime sinão parcialmente a plenitude de sentido que se encontra na palavra. Alguns eruditos a suspeitaram: F. Müller enccntrou uma explicação engenhosa, muito engenhose, sem dúvida, de todo o apolinismo do Carmen: segundo êle, a expressão, tomada num sentido muito próximo da etimologia da palavra (por augeo), recobre, sob a divindade de Apolo, a personalidede de Augusto..." "Assinalemos desde já êste resultado: Apolo, no poema de Horácio, aparece, como para Tibulo (135), sob o aspecto do augur supremo- (136)," .,

Eram replicadas, assim, as profecias que, fazendo de Roms uma cidade do mal, previam o seu castigo e a sua queda, e ainda aqui notamos um fato digno de menção: Augusto mandou amon. toar e queimar mais de 2.000 volumes de predições ern. língua grega latina, trazidos de tôda a parte, cujos autọes eram anónimos ou pouco recomenđáveis, e conseryou sòmente os livros sibilinos, mas sujeitos, também, escolha. Feito isto, encerrou-os em duas caixinhas douradas e colocou-os no soco da estátua de Apolo Paletino (137). Suetônio nāónos diz qual o conteúdo de tais predições, mas - diante de tudo que acima ficou exposto - não é dificil imaginar-se que tais profecias não deverism ser favoráveis ao destino da cidade, e o fato de ter sido confiado a Apolo o que sobrou da escolha parece-nos significar que a êste deus, como divindade estreitamente ligada à Sibila (138), coube presidir a cerimônia da queima das más profecias. Quianto aos livros sibilinos, cujo texto não nos chegou, foram êles confiados a Apolo Palatino, cujo

(133). - Teja-se a inscricto do Triene o Jiscurso de Nicolau de Damasco

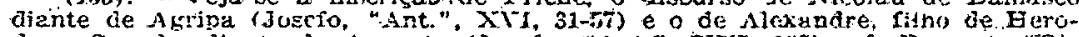

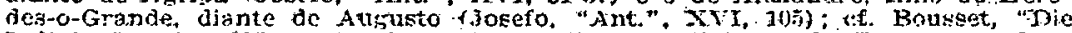
Letigion". pug. 22.: Guímeibert, "La politique religiense de Rome aux dous

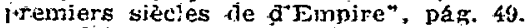

(19i). - "augur et fulgente decorus arcu"...

(13.5). - II, $5,11-15$.

(136). - "Recherclies...". páss. 29-33.

(137). - Suetónjo, "Augisto". 31; cf. Tácito,"Anijü" VI, 12 Segundo

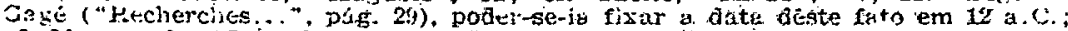
rf. Marquardr, "Ire culte chez les Romains", T1, jiag. $4 \dot{j}$.

(138). - Cf. Diarquardt, op. cit., II, pag. Es e ss... 
templo erguia-se na mesma colina em que Rómulo criminasamente fundara Roma; e, certamente, isto teria sido feito com a intençăo de colocar o futuro da cidade, centido nas profeciás, sob a guarda do renovador que a purificara de seus crimes: o deus Apolo.

Era, de fato, como se Augusto houvesse restaurado Roma, e nada mais compreensivel do que sua consagração pelos contemporáneos como um novo fundador dz cidade. Suetônio nos diz, mesmo, que "certos senadores prcpuzeram que éle fósse chamado Rômulo, como sendo o segundo fundador da cidade, mas foi o cognome de Augusto que prevaleceu, tanto por causa de sua novidade como pelo seu caráter mais grandioso, porque êste térmo, derivado seja de "auctus", seja da expressão "avium gestus" ou "gustus", aplica-se igualmente aos lugares santificados pela religião e ncs quais se fêz uma consagração qualquer, após terem sido tomados os augúrios, como o indica mesmo o verso de Enio: Depois que Roma foi fundada sob augustos augúrios (139)." Hubaux, comentando esta passagem, vé nela a intenção manifesta de atribuir a Augusto o papel de segundo fundador, uma vez que a citação de verso de Enio teria como função única a de lembrár os augúrios tomados por Rômulo quando da fundação da cidade. Mas, ao mesmo tempo, ligando o têrmo "Augustus" à idéia de "augere", o autor indicaria claramente que a segund fundação tivera um caráter bem mais magestoso do que a primeira. Otaviano-Augusto é, Iiteralmente, o Funciador de Roma (140), e um fundador bem mais paderoso e digno de elogios, porquanto fundamenta sua obra no Bem, e não no Mal, como nos diz o paralelo estabelecido por Ovídia:

Rômulo, cede-lhe o passo: éle fêz grandes

Os muros que, de um só saito, Remo póde atravessar.

Tu venceste Tatius e Curc, uma aldeia;

O mundo inteiro, sob êle, tornou-se romano.

Tu conquistaste nāo sei que pequeno canto de terra:

César possui todo o espaço sob o céu.

Tu fizeste, por teus soldados, roubar as sabinas:

Ele vela, por suas leis, söbre a virtude das mulheres.

Tu forneceste um asilo aos bandidos, num bosque:

Ele, suprime o mal em todo o seu vasto imperio.

(139). - "Augusto", 7. "iemprunte au vocabulaire angural, il se trourait ascocí de mès au souvenir de Fomulu, doù l'hesitation signalée par Suétone"

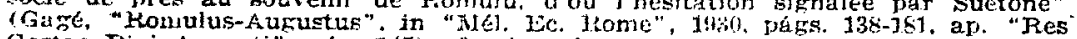
Gestae Divi Augusti", pár. itb). ijuchan dostaca o. papta gue teria sido desemponhado por Mecenas na escolha do cumone err questäo: "He (Augusius) would hive preferred "Pomulus". "hom Ronie bad alwiys saluted as the leader who had brought her out of darliness into lizht; Home's second founder fhould have the appellation of lier first. Put rowulus had been a king, and the most zistant monarchical sugsestion liust be arvided. "Augustus". which met with nn criticism, was probably the idea of Njecents, the "cminence prise" in the backeround, and it was cuntingly chosen" "Augustus". pág. 140.3).

(140). - Hubaux, "Les grands mythes de lono", pac. 1]s. Fouco adianto. faz notar o mesmo autor que una lenda fosterior mi morte de A ugusto. c que se encontr. nenciunada em d. Obsequons. Suetonio ("Augusto", 95), $E$ D. Caggio (XIYI, 1 ), dava-o como tendo tambem visto os 12 abutres que surgiram 3 "Romulo, quando da fundaç̄o da cidade. Cf. Buchan, "Augustus", pág. 61. 
Tu te sentes bem na fôrça, - êle faz florescer o Direito.

Tu tomas o nome de "Senhor", - êle se diz: "o primeiro".

Remo te acusa, - éle faz graça aos inimigos.

Tu foste deus por teu pai - êle féz deus o seu (141).

E' claro que a esta benéfica Roma de Augusto adatar-se-ia de maneira muito mais própria o tema da eternidade, que já vimos tratado por Virgílio na "Eneida". De fato, a purificação, o benefício que a cidade regenerada por Augusto prestava ao mundo, faziamna merecedora da perenidade e, até mesmo, da divinização. E não será demais lembrar-se que o estoicismo pode não ter sido extranho a esta evolução para a divindade de Roma regenerada, dado que, para a Estoa, a virtude era de natureza divina, e a melhor espécie de virtude era a de auxiliar a humanidade, tanto que "amar e ajudar a humanidade é a obra e essência verdadeira de Deus (142)." E não correspondia a isto a obra de Roma, impondo e garantindo a paz no mundo? - E não o fizera ela graças a Augusto? - Compreende-se, assim, o texto de algumas inscrições da época:

"Augusto, ao mesmo tempo-Pai de sua Pátria, a deusa Roma e Júpiter nacional, Salvador da comunidade da espécie humana (143)."

Consumava-se, dêste modo, a transformação de Roma, de entidade do Mal e da fatalidade, em benfeitora, símbolo da par e da ordem (144). "Fechara-se 0 anel dos tempos. Augusto expiara a antiga culpa de sangue $e$ inaugurara um periodo de felicidade. Despontara a Idade do Ouro; como remate aos saecula anteriores; - Direito, a Justiça e as Virtudes, que haviam abandonado o mundo durante os terriveis tempos, faziam novamente a sua entrada. Respirava a cansada humanidade e alegrava-se com a paz tão longamente desejada (145)." Já, agora, "o boi pode, sem perigo, ir e vir pelos campos. Os campos têm, para nutrí-los, Ceres e a Felici-

(141). - "Fastos", II, i33 e ss.; cf. Fubaux, op. cit. ,pág. 121. Aliás, o próprio Kómulo recebera un oráculo, segundo o qual Roma seria grande na medida em que confiasse seus destinos i zuerra (Plutarco, "Romulo", 14, 2); cf. Dumbzil. "La naissance de Rome". phig. 124-202: Freyer. "Weltgeschichte Türopas", pags. 538-539: "Und kijer tritt nun die eigne Grösse des Augustus in die Erscheinung, der keir Nachfolger sondern ein Beginner ist, kein Erbe les Friedens, sondern ein Prinfer des Friedens, nämlich dadurch, dass er Mass hiilt im Sieg, den triumph durch Yersöhnung adelt und die verschütteten Quellen wieder erschliesst, aus denen Roms frühere Uintracht geflossen ist".

(142). - Murray, "Five stages of Greek religion", pág.158. Podem-se encontrar ainda outros tracos estóicos na celebracão de Augugto assim como o papel af desenjpenliado pela Providencia (cf. a inscriçāo de Priene, ap. Jeanmaire, "Le messianisme de Tirglie", pág. 150).

(143). - Inscrição de Halicarnasso (n.o 894 das inscriçôe do British Museum), ap. Wendland, "H.M.K." pág. 102. Cr. Charlesworth, "Providentia et Anternitas", pág. io9.

(144). - Murray, "Stoic, Christian and Humanist", pág. 27.

(145). - Wendland, "H.R.K.", pág. 143. C\&. Hórácio, "Carmen Saeculare". $57-60$. 
dade benfeitora; sôbre o mar pacificado circulam, em todos os sentidos, os marinheiros (146); enfim, viver é novamente um prazer.

* * * *

A partir da época de Augusto a idéia de Roma foi sendo cada vez mais ligada à de permanéncia, de estabilidade, de eternidade, elementos que iam se associando à cidade que, pondo fim ao pluralismo pclítico no Mediterrâneo, tornara-se a cabeça única do mundo antigo (147). As crises políticas podiam, por vézes, abalar os espiritos (148), mas a confiança renascia, como, por exemplo, na época dos Flávios, após a confusão a que dera lugar a morte de Nero. Não tivesse sido ràpidamente suprimida a anarquia do ano 69 e a civilização međiterrânea poderia ter ficado sob grave ameaça; o Império estava ao desamparo e em perigo (149), mas foithe restituida a seguranca, sendo salvos os oitocentos anos de fortuna e da conduta que haviam elevado êste vasto edifício (150). A todos os povos e províncias ccmpreendidos no Império a dinastia Flávia restituiu aquela confiança no permanente vigor de Roma, na sua aeternitas, que tremera, mas apenas por um momento; tal era a mensagem das moedas, que prometiam AEternitas e ligavam aquela promessa ao princeps (151). Um flagrante exemplo dêste sentimento sobreviveu numa inscrição de Acmônia, na Frígia, pela qual se vê que a cidade recebera considerável benefício graças a um rico cidadão; o Senado e o povo decidem, então, como deve ser gasto o dinheiro, seguindo-se a cláusula - "e êste decreto será garantido pela eternidade do império dos romanos (152)." Estava restaurada, assim, a crença no poder permanente de Roma (153)., na mesma época em que o "Apccalipse" denunciava um recrudescimento da: ira dos judeus contra a cidade, já agora consagrada como "Urbes AEterna".

Outro elemento acrescentcu-se ainda a esta crença, elemento êste que - pcdemos dizer - deveria ter uma espécie de função preventiva, impedindo que Roma se tornasse irreminediàvelmente velha, embora não devesse morrer (154). O mito da deusa

(13i).,- Horicio, Odes, IV, 7, 17-19: ef. Suetonio, "Augusto", 98. Buchan,

"Aurustus", pags. 27- 286.

(1+i). - Cr. Plinio. "Naturalis Ihistoria", XIV, 2; XXVII, 3; XXXVI, 118

(1ib) - is que se observa, por exemplo, com Lucano; cf. Rehm, "Der Un.

terging Kons". púg. 14; Guissier, "La religion romaine". I, páge. 216-217.

$(1+19)$. - Cr. Suetónio "Vespasiano", 1 .

(1.0). - Titcito, "ilistorias". IV. T4.

(15i) - Cr. Ciarlesworth. "Providentia et Aeternitas", pag. 126-127 e 130.

(152). - Inscriptiones Graecae af res Romanas pertinentes, IV, 661, ap. Char-

leyworth, in "Cambridze ancient History", XI, pag. 45.

(153). - Charlesworth; op. cit., pags. 4-45.

(154). - Sezundo Hubaux a ideia do rejuvenescimento prender-se-ia ao evisodio nartado pela Sibita a Enejas, de äcordo com o qual teria ela conseGuido de Apolo a longritidade, mas nio a juventude: cf. Ovdjo, "Metamorfoses. XIV, 130 (Hubaux. "j,es trands mythes de Rome". ph.g. 48). Dlante disto, assim teriam raclocinado og romanos: "Ah! si Rome avait pu se Laire conferer 
Juventas, como já vimos, servia de base para isto, mas só na época. dos Antonincs, no explendor do Império, é que o rejuvenescimento de Roma aparece ccmo um novo aspecto externo da crenca na existencia das idades e da renovação cíclica, o que se pode ovservar pela ccnhecida passagem do proêmic do "Resumo de Histónia: romana", de Floro:

"Considerandone, então, o povo romano como ura só homem, encarando-se tóda a seqüência de sua idade, seu nascimento, siáa adolescência, a flor, por assim dizer, de sua juventude, e enfim, a espécie de velhice a que êle chegou, encontrar-se-á sua existência partilhada em quatro fases e periodos."

"Sua primeira idade passou-se sob os reis, no espaço de perto de duzentos e cinqüenta anos, durante os quais lutou êle, em tôrno de seu berço, contra as naçóes vizinhas. Estaria lá a sua infância."

"A idade seguinte, desde o constilado de Bruto e de Colatino até $\circ$ de Ápio Cláudio e de Quinto Fúlvio, abrange duzentos e cinqüienta anos, durâtite os quais foi subjugada a Itália. Este periodo agitado foi fecundo em guerreiros, em combates; também, pode-se chamá-jo a sua adolescência."

"Dai atế César Augusto, escoaram-se duzentos anos, que fo-" ram empregados na pacificação de todo o universo. Trata-se, então, da juventude do império e de sua robusta maturidade. Desde César Augusto até os nossos dias: não se contam menos de duzentos anos, durante os quais a inércia dos Césares como que o féz envelhecer e enfraquecer-se inteiramente. Mas sub o reinado de Irajano, êle reenconira suas fórças e. contra tôdas as esperanças, este velho império, como que restittido à juventudie, rctoma o seu vigor."

Pouco adiante o mesmo autor nos dá a sua fonte de inspiraçäo, com o mito de Juventas e Terminus, ao qual já vimos referências até em Tito Livic (155). Assim, pouco a pouco, completava-se o processo da crença no perene poder de Roma, no "Imperium sine fine" da "Eneida", através das seguintes grandes etapas: expiação dos pecados por meio dos benef́cios feitos ao mundo graças ذ̇ paz; purificação e refundação por Augusto; eternidade e rejuvenescimento.

Resta-nos ver agcre, para terminar êste capitulo, a maneira pela qual os autores cristãos acolheram tais idéias, a partir do seu đesligamento da apocaliptica judaica (156). Cabe aqui, inicialmente, uma observaça referente à maneira como os cristäos po-

par surciof lapterne juventa que in disenso de sorts, toute voote et toute rade par sid pesante senilite. remrettait de n'aroir acceptese pour elle-meme". ff. Fohns, "Der Untergang Roms im abendlindischen Denken", nág. 17.

(15i). - 1. vil - "Todavia, s! construil un tempio com os despojos das ridades que hivin tomado. Quinto fol du inauguracaso, os outros deuses cede-

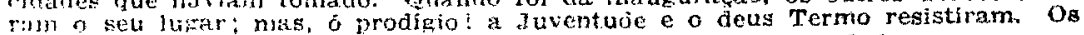
adivinhe mtaphotaran favorivelmente a toimosia destas divindades, que prome-

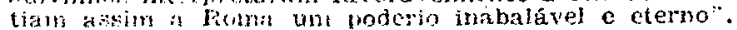

$(17, j) .-$ Noto-sc entretanto, que náo poderia ser posto de lado, em bloco, repuntinaincnit. toils o tomento apocaliptico judeu, e que certas remitiscenclas.

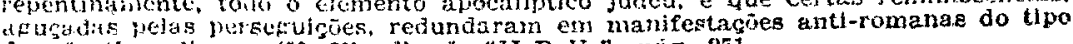
las de Cumodiano. Of. Wendland, "H.R.K.", pák. 251. 
derim conceber a "eternidade" de Roma; acreditavam êles que "o fim do mundo e o reino dos céus estavam a ponto de chegar. A aproximaçäo dêste acontecimento maravilhoso tinha sido predita pelos apóstolos; seus mais antigos discípulos tinham conservado tal tradiçäo; e aquêles que explicavam literalmente as palavras do próprio Jesús Cristo declaravam que o Filho do Homem ia logo aparecer nas nuvens e que Ele desceria de novo sôbre a terra em todo o briliho de Sua glória..." "Os cristãos viviam, então, à espera deste momento em que o glcbo terrestre e tôdas as diferentes raças de mortais deveriam tremer ao aspecto de seu divino Juiz (157)." Evidentemente, nestas condiçốes, Roma seria também abrangida no fim do mundo (158) e mesmo com o enfraquecimento da "febre escatológica" (159), os cristãos não poderiam crer na sua eternidade da mesma forma que um pagão convicto e confiante ros destinos da cidade imperial.

Mas, dentro desta limitaçã̃o, notamos que os adeptos do Cristientismo aceitavam a idéia da permanência de Roma, enquanto o mundo existisse e que, ainda mais, ligavam os destinos de tôda a Terra à existência do Império Romano; "o domínio de Roma era universal e, assim, devia ser "eterno". Nada fora visto antes que se The comparasse. $O$ império de Alexandre durara muito pouco tempo e dentro dêle havia muitas regiões áridas em que ninguém a não ser selvagens - havia posto o pé. O. de Roma durava já havia muito, abrangia tôda as mais populosas e melhores regiões do mundo civilizado e lançara tão profundamente as bases de seu poder, que parecia destinado a durar para sempre.(160)." Bastante elucidativa a respeito da maneira pela qual os cristãos também consideravam-se ligados aos destinos de Roma é a conhecida passagem de Tertuliano:

"De fato. o império não pode ser abalado sem que o sejam todos os seus membros: e nós próprios, ainda que o povo nos considere como excluidos do Estado, também nós nos encontramos envolvidos nas suas infelicidades."

"Temos, aliás. uma particular razão de orar pelos imperado res. e mesmo por todo o Império Romano. e é que nós sabemos que o fim do mundo, com tôdas as terriveis calamidades que devem precedè-lo. não é retardado senão pela existência do Impé-

(155) - Tal espera fundamentara-se principalmente no Evangelho de São ihateus, cap. 24 c na primeira epistola de São Pauio aos Tessalónicos. Cf. Gibhon. "Histuire de la décadence et de la chute de ?'Empire Romain". I, pág. PSO: Wendlns, "F. R.K.", pág. 251; Boissier, "La Fin du Paganisme", II, pág. 390.

(15\%). - Gombel, "La naissance du Christianisme", pag. 481; Schmidt. "Le problène du Ghrigtianisine primitif", páe. 99.

(15月). - Cr. Goguel, "La seconde gérération chrétienne". I, pag. 35; idem, "isa naiksance du Cli:istianisme". pags. S00 e ss.; Guignebert, "Le Christianisme antique", pág. 142. Note-se que o poeta Iuvêncio, por exemplo. no século $T$. desenvolvia o tema de que nada era inortal sobre a terra, nem mesmo foma (Cr. Courcelle, "Histolre litteraire des grandes invasions germaniques", píg. 13). (160). - Ervce. "The holy Roman I Empire", pág. 20: Cf. Gunter, "Die Frachside Im Wandel der Zeiten", in "Historisches Jahrbuch", Band 53, 1933, Dags. 409-128. 
rio Romano. Pedirido a Deus para nos poupar o expetáculo desta catástrofte, nós pedimos, por conseguinte, que à duraçấo $30 \mathrm{im}$. pétio seja proiongada (161)."

E êstes trechos pertencem a uma obra escrita antes da contaminação de Tertuliano pela heresia montenista (162) a qual, por sua vez, deveria contribuir para divulgar as crenças milenaristas que determinavam, sob outro aspecto (muito semelhante, aliás, às esperanças no advento da Idade do Ouro), mais um elemento restritivo à "eternidade" de Roma.

Tais crenças milenaristas, que tantos partidários tiveram, de tal modo que desde São Justino e Santo Irineu até Latâncio todos os Padres da Igreja delas se ocuparam (163), consistiam em que, aos seis mil anos contados desde a criação, e que corresponderian aos seis dias das obras do Senhor (164), seguir-se-iam mil anos de completa felicidade, sob o reinado de Jesús Cristo. Mas, mesmo entre os milenaristas, encontramos a aceitação - ou meihor - a adatação ao Cristianismo, de idéias pagãs que, ligadas ao grande ciclo da lenda de Roma, facilitariam a transmissão da crença na "perenidade" da cidade (pelo menos enquanto durasse o mundo), da esfera pagã para a cristã. Observe-se, por exemplo, em Mélito de Sardes, dirigindo-s z ao imperador Marco Aurélio, a seguinte passagem que, apesar de ser um tema comum de apologética, despido de reflexões político-teológicas, não deira de ser interessante para o nosso caso:

"E uma muico grancie prova da exceléncia da nossa filosofia que ela se tenha descnvolvido ao mesmo rempo que a feliz ins. tituição do império e que, desce então. a partir do reinado de

(161). - "Apologetica". XXXI-XXXIi. Cr. can. XXX1X; "ad scamam". i, $2 ;$ d'Ales. "La Thélogie de Tertullien". Hag. tug ans. Ainda que se xdote - ponto de vista de Guignebert i"rertullien, étude de ses sentianents a t'egard de lempire et de la société cirile", pág. Itô, ap. d'Alès, op. cit. pág. $403-404$, nnta 3), de que Tertuliano $e$ sempre inizaigo do Inperio, tä́o deixa de ser signi. ficativo que estes scjam os térmos em que tal inimigo se expressa. Ce. Graf, "Roma nclla nemoria e nelie innaginazioni jel Medio Evo". II, pág. 472; Lot, "Ía fin du monde antique et le début du Moyen Age", pá. 295; Goguel, "La reconde generation chretienne", 2 , pias. 45.

(102). - Pichon, "ilistoire de la litterature latine", pag. 739, nota 1. W verdade que, ainda assim, tal trecho ja pode ser considerado como um reflexo das preocupaços milenaristas. tão marcantes ná época. (cí. d'Alès. op. cit.. págs. 3 in $44(1)$. De qualquer maneira. porem. julgamos isgica a anotacáo que fazemos. porquanto tal traco foi exagerado pelos montanistas (cf. Labriolle. "Histoire de la listerature latine chrfienne". pig. 89). Que Tertuliano deu granie mportancia ao milenarismo, vitesta-o fato a cue tenha escrito um trabalho dedicado ao assunto - "Ine spe fidelium" - que nâto chegou até ros fof. Leclerq. art. "Minlenarisme", in "Dictionnaire d'archeologie chretienne et de liturgie" i.

(163). - Gibben. op. cit. I. jaE. 281.

(164). - Tais seis mil anos estariam quase completos, porquano a igroja prinitiva de Antioquia avaiava em perto desta cifra o numero de anos decorrilos desde a Criaçâ ate o ráscimento de Jesís Cristo. Cr. Gibbon. or. cit., par. $2 \$ 0$, notit 2: Lecira, art. in loc. cit.; sobre as origens judaicas do milenerismo, cf. Harnack, art. "Millenium", in Encjclopedia Dritanaica". e Eirscin, artigo sob identico título in "The Cathoiic Encyclopedla". 
Augusto, nada de lamentável haja acontecido, mas que, ao contrário. tudo tenha sido brilhante e glorioso, segundo os votos de cada um (165)."

Assizn, a religião surge como júma fonte de benefícios para o Império, e é manifesta a intenção de estabelecer entre Augusto, fundador do Império e renovador de Roma, e o Evangelho, uma estreita ligação. Se continuarmos a nossa pesquisa, vamos encontrar em Latâncio, êle também milenarista (166), têrmos tais que permitem que se fale já "num sentido ideal, em uma Idade Augusta Cristã, em um Império Cristão Ideal." O mundo acabará em breve, mas o colapso universal não pode ocorrer enquanto existir a cidade de Roma, que é o pedestal do mundo(illa, illa est civitas quae adhurc sustentat omnia), e quando ela cair, então ninguém poderá duvidar de que chegou o fim đas cousas humanas, da própria terra. Ela ela só é a causa pela qual tôdas as cousas têm sido até agora mantidas; "eis porque devemos fazer preces e súplicas ao Deus do Céu, se na verdade seus decretos e intenções, podem ser deferidos, para que aquêle odioso tirano não venha mais cêdo do que nós esperamos, êle para quem estão reservados feitos temerosos... (167)."

A IV écloga, por sua vez, é adatada ao Cristianismo, resultando daí a crença em que Jesús Cristo fôra a criança cantada por Virgílio; seu nascimento marcaria, então, o início de uma nova Idade do Ouro mas, evidertemente, ao mesmo tempo que Roma atingia o fastigio de sua carreira com Augusto e o Império (168). Cristo, Roma e Idade do Ouro, estariam assim intimamente relacionados.

Por fim, a própria regeneração e refundação da cidade, tal como a vimos sob Augusto, será apresentada sob um aspecto cris-

(165). - Apud Eusébio, "Historia Ecclesiastica". T, 26, 7. Cf. Labriolle. "La réaction paienne", páss. 71-72; Peterson. "Der Nonotheismus als politisches Froblem", pags. 70-71: Hahn, "Das hiaisertum", páes. 35-36. Boissier, "La Fin du Paganisme", Il pág. 30z: Parkitt e Laynes. in "Cambridge Ancient History". XI1. pázs. 461 e 661: Harnack, "Missione e propagazione". págs. 199-200. Poder-se-ia supor tratar-se apenas de lisonja, mas Harnack, que sugere a hipótese, * o primeiro a combaté-la imediatamente.

(166). - Esperava o fim do hundo para una data dentro dos prúximos 7uzentos anos of "Nivinarum Institutionum", VI1, 25, 3-5), Cf. Labriolle. "Histoire de la. littérature latine chrétienne". paz. 2T. í o milenarismo que o impede de aceitar o rejurenescimento de Roma, se ben que mencione a divisão em perodos, de maneira semelhante à de floro. mas atribuindo-a a Séneca ("Divinarum Institutionum!". VII, 15: cf. Migne, "Patrologia Latina". vol. 6, nota a ao referido capituioi.

(167). - "Divinarum Institutionum", T11, 25. Cr. Bryce, op. cit., pág. 21; Rana. "rrhe building of eternal Fome". pig. 201.

(165). - Trata-se da oracino de Constantino. que nos foi transmitida por Eusébio ("De vita Constantini". N. 3); cf. Rand, op. cit.. pág. 200: Boissier, "Le religion comaine". I, págs. 257 e ss. :Prümm. "Der christliche Glaube", I. nag. 208; idem, "Seltsame Heilandsuropheten", págs. 622-623. Lima lenda medicval eatabeleceu também a relaçáo entre Virgllio e São Paulo, dizendo que o apóstolo, de passagem por Nápoles. fôra visitar o tumulo do poeta ; Iá. derramando viedosas lágrinas sobre o mausoléu. teria exclamado: "Que homem teria eu feito de $t$, ge te houvesse encontrado vivo, o o naior dos poetas!" (Comnarett, "Virgilio nel meio Evo", 1 , pég. 128 e. ss., ap. Boissier, "La religion roukine", I, pág. 262). 
täo, no famoso sermāo do papa Leäo $I_{3}$ "In netali apostoiorum $P$ etri et Pauli (169)."

Assim sendo, julgamos caber aqui a seguinte pergurta: que grande fator teria tornado possível tảo completa aceitaçâo (ben entendido, dentro dos quadros do Cristianismo), de crenças pagãs igadas à cidade de Roma? - A nosso ver, pelo menos, qualquer resposta baseada em fundamentos de ordem exclusivamente sentimental - como o "sangue dos mártires" - ou exclusivamente política, seria muito simplista e falsearia a realidade histórica. Só. mos de opinião que tais fatos podem não ter sido extranhos a isto, mas parece-ros que só êles seriam insuficientes, se razões mais profundís não determinassem a referida aproximação. E'o que passamos a ver.

(Continua no ptoxmo numes)

PEDRO MOACYR CAMPOS

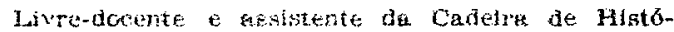
ria da Civilyação Antlga e Medieval (ti.S.F.).

(160). - Sermão, LXXXII, in Migne, "Patrologia latina", tomo LIV. C, Gregorovius, "Storia della citts di Fona nel Medo Evu", i, pag. 8; Grianar, "Fom beim A usgang der untiken Helt", pág. "ro. 